\title{
Spatial and vertical extent of nucleation events in the Midwestern USA: insights from the Nucleation In ForesTs (NIFTy) experiment
}

\author{
S. C. Pryor ${ }^{1}$, R. J. Barthelmie ${ }^{1}$, L. L. Sørensen ${ }^{2}$, J. G. McGrath ${ }^{3}$, P. Hopke ${ }^{4}$, and T. Petäjä ${ }^{5}$ \\ ${ }^{1}$ Atmospheric Science Program, College of Arts and Sciences, Indiana University, Bloomington, IN 47405, USA \\ ${ }^{2}$ Department of Atmos. Environ., Aarhus University, Roskilde, Denmark \\ ${ }^{3}$ School of Physics, NUI Galway, Galway, Ireland \\ ${ }^{4}$ Chemical and Biomolecular Engineering, Clarkson University, Postdam, NY 13699, USA \\ ${ }^{5}$ Department of Physics, University of Helsinki, Helsinki, Finland
}

Received: 1 September 2010 - Published in Atmos. Chem. Phys. Discuss.: 8 October 2010

Revised: 8 January 2011 - Accepted: 12 February 2011 - Published: 21 February 2011

\begin{abstract}
Measurements of aerosol particle physical and chemical properties, gas phase concentrations and meteorological parameters were made along a transect in southern Indiana during the Nucleation In ForesTs (NIFTy) experiment conducted in May 2008. These measurements indicate nucleation was observed at all three measurement sites on almost half of all sampling days. The intensity of the nucleation events, as measured by the increase in $\geq 10 \mathrm{~nm}$ aerosol particle number concentrations of approximately $2 \times 10^{4} \mathrm{~cm}^{-3}$ over a layer of at least $300 \mathrm{~m}$ depth, is in good agreement with recent model results for the Midwestern USA derived using PMCAMx-UF. During the hour after termination of nucleation approximately half of the number concentration reduction is due to coagulation, while the remainder is due in equal parts to dry deposition and entrainment of relatively ultra-fine aerosol particle free troposphere air. Clear nucleation with continuous subsequent growth is only observed on days when the morning fractional cloud cover was less than $30 \%$. It is associated with a clear transition from a strongly stratified atmosphere with low turbulence intensity and weak vertical velocities, to much a weaker vertical gradient of wind speed, increased turbulence intensity and stronger downwards vertical velocities, consistent with growth of the mixed layer and entrainment of air from the residual layer. Nucleation intensity is not very strongly determined by the prevailing condensational sink. However, there is a strong correlation between both a modified version of the Nucleation Parameter from Boy and Kulmala (2002) and
\end{abstract}

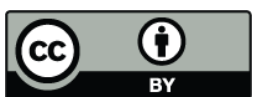

Correspondence to: S. C. Pryor (spryor@ indiana.edu) ultrafine aerosol particle number concentrations, and mean morning $\mathrm{H}_{2} \mathrm{SO}_{4}$ concentrations and ultrafine aerosol particle number concentrations. Five A-class event days during NIFTy were characterized by values of the dimensionless nucleation parameter of Kuang et al. (2010) that are below 0.3, further indicating the applicability of their postulate that nucleation is favored by $L_{\Gamma}$ values below 0.7 . Based on aerosol particle composition measurements it appears that aerosol particle formation and initial growth to approximately $30 \mathrm{~nm}$ diameter is dominated by ammonium and sulfate. Conservative estimates of the percent contribution of $\mathrm{H}_{2} \mathrm{SO}_{4}$ to aerosol particle growth (for sub- $30 \mathrm{~nm}$ aerosol particles) on five Aclass event days ranged from 23 to $85 \%$.

\section{Introduction and objectives}

Atmospheric aerosol particles affect climate both directly by scattering incoming solar radiation back to space and indirectly by acting as cloud condensation nuclei. Direct and indirect climate forcing by aerosol particles are two of the most uncertain parameters in past and future global change (Alley et al., 2007; Schwartz et al., 2010). Model simulations indicate nucleation i.e. gas-to-particle conversion is a significant source of aerosol particles in the global atmosphere (Spracklen et al., 2006; Yu and Luo, 2009), and there is experimental evidence that new particle formation is a worldwide phenomenon (Kulmala and Kerminen, 2008; Kulmala et al., 2004; Manninen et al., 2010). However, to assess model uncertainties and constrain climate projections, additional distributed measurements of aerosol particle concentrations and properties and related modeling are required.

Published by Copernicus Publications on behalf of the European Geosciences Union. 
The Nucleation In ForesTs (NIFTy) experiment was conducted in southern Indiana in the eastern USA during 5-31 May 2008. Simulations of the eastern USA during 12-28 July 2001 indicate $\geq 3 \mathrm{~nm}$ aerosol particle concentrations in the vicinity of the NIFTy sampling sites were $4 \times 10^{4} \mathrm{~cm}^{-3}$ (for $\geq 10 \mathrm{~nm}$ aerosol particles the concentration was approximately $2 \times 10^{4} \mathrm{~cm}^{-3}$ ) and exhibited a three-fold increase in near surface $\geq 10 \mathrm{~nm}$ aerosol particle concentrations when a scaled version of a ternary nucleation scheme was turned on relative to a no-nucleation simulation (Jung et al., 2010). Consistent with that model analysis, two years of continuous aerosol particle size distribution measurements at the central forest site used in the NIFTy experiment exhibit evidence of nucleation on $46 \%$ of classifiable days, and clear nucleation with consistent subsequent growth on $14 \%$ of days (Pryor et al., 2010). The context for and objectives of the NIFTy experiment were as follows:

1. To examine the spatial scales of nucleation and variations in ultra-fine aerosol particle characteristics in locations with differing land use and emission profiles. Prior research has shown gas-to-particle conversion occurs on regional spatial scales as indicated by ground based measurements upto several hundred kilometers apart (Dal Maso et al., 2007; Hussein et al., 2009; Jeong et al., 2010; Komppula et al., 2006; Wehner et al., 2007). These events, while nearly coincident in time, have site-specific characteristics (Hussein et al., 2009). Prior research has also shown qualitatively similar behavior in ultrafine size-resolved aerosol particle concentrations at upwind rural sites and downtown urban areas over scales of 10's of km (Stanier et al., 2004b, a; Yue et al., 2009). Accordingly, during NIFTy measurements were taken along an $80 \mathrm{~km}$ transect extending from the small town of Bloomington to the southwest, to the central long-term measurement forest site (in Morgan Monroe State Forest (MMSF)) and up to northeast Indianapolis to examine meso-scale variability in aerosol particle properties (Fig. 1). The vertical extent of new aerosol particle formation is uncertain, with evidence for both new aerosol particle formation at the surface layer mixing upwards (O'Dowd et al., 2009) and nucleation occurring aloft and subsequently blended downwards (Siebert et al., 2004). New aerosol particle formation frequently occurs concurrently with the destruction of the night-time stable layer and subsequent formation of the mixed boundary layer. Typically the time for mixing and for the growth to detectable size occurs in approximately same time scales (Nilsson et al., 2001), thus differentiating between the two theses is difficult. Further, increased turbulence could enhance the concentrations of nucleating species on a small scale and possibly facilitate the initial formation of new aerosol particles (Lauros et al., 2007; Lauros et al., 2006; Nilsson and Kulmala, 1998; Wehner et al.,

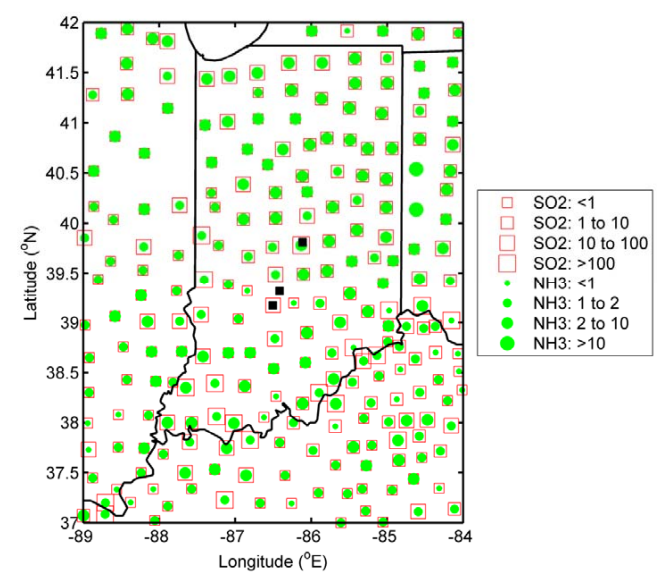

Fig. 1. Location of the sampling sites (v); Bloomington $\left(39.171^{\circ} \mathrm{N}\right.$, $\left.86.506^{\circ} \mathrm{W}\right), \operatorname{MMSF}\left(39.317^{\circ} \mathrm{N}, 86.417^{\circ} \mathrm{W}\right)$, and northeast Indianapolis $\left(39.811^{\circ} \mathrm{N}, 86.114^{\circ} \mathrm{W}\right)$, and county-level aggregated emissions of sulfur dioxide $\left(\mathrm{SO}_{2}\right)$ and ammonia $\left(\mathrm{NH}_{3}\right)$ in 2002 in tonnes per square mile (data available at the EPA AirData portal; http://www.epa.gov/air/data/reports.html). Annual average $\mathrm{NH}_{3}$ and $\mathrm{SO}_{2}$ emissions in southern Indiana are estimated to be approximately 46 and 2.3 tons per square mile based on this inventory. The $\mathrm{SO}_{2}$ emissions derive principally from point sources with elevated effective emission heights, while $\mathrm{NH}_{3}$ emissions are predominantly from ground-based agricultural sources (Pryor et al., 2001).

2010). Thus, to examine the vertical extent of nucleation and the fate of recently nucleated aerosol particles we flew instrumentation on an unmanned aerial vehicle (UAV) from a small private airfield on the southern portion of the experimental transect between Bloomington and MMSF (Table 1).

2. To examine the meteorological context for nucleation events. Certain synoptic scale meteorological conditions, particularly cold front passages, appear to be associated with nucleation, in part because they are associated with a reduction in the sinks for freshly formed aerosol particles and condensable vapors. Further, since analyses of other long-term data sets have indicated preferential occurrence of nucleation with specific back-trajectories (Coe et al., 2000; Fiedler et al., 2005; Hussein et al., 2009; Komppula et al., 2006; Young et al., 2007), the synoptic context was examined and 24$\mathrm{h}$ back trajectories were computed for every classified day of data from MMSF using the HYSPLIT model. Analyses of local meteorological conditions, described using metrics such as the Nucleation Parameter (NP) of (Boy and Kulmala, 2002) and atmospheric stability indices (based on the Monin-Obukhov length), have indicated nucleation is frequently preceded by destabilization of the atmosphere possibly associated with entrainment of elevated pollution layers (Nilsson et al., 2001). Vertical profiles of aerosol particle measurements and 
Table 1. Instruments deployed during the NIFTy experiment conducted during May 2008.

\begin{tabular}{|c|c|c|c|c|}
\hline Location & $\begin{array}{l}\text { Latitude } \\
\left({ }^{\circ} \mathrm{N}\right)\end{array}$ & $\begin{array}{l}\text { Longitude } \\
\left({ }^{\circ} \mathrm{W}\right)\end{array}$ & Instrument & Measurement (and height) \\
\hline Indianapolis & 39.811 & 86.114 & Fast Mobility Particle Sizer (FMPS TSI 3091) & $\begin{array}{l}\text { Aerosol particle number size distributions } \\
(10-200 \mathrm{~nm}) @ 5 \mathrm{~m}\end{array}$ \\
\hline MMSF & 39.317 & 86.417 & Fast Mobility Particle Sizer (FMPS TSI 3091) & $\begin{array}{l}\text { Aerosol particle number size distributions } \\
(6-400 \mathrm{~nm}) @ 46 \mathrm{~m}\end{array}$ \\
\hline MMSF & 39.317 & 86.417 & $\begin{array}{l}\text { Scanning Mobility Particle Sizer (SMPS TSI } \\
\text { 3936; EC3081, nano-DMA, CPC3786) }\end{array}$ & $\begin{array}{l}\text { Aerosol particle number size distributions } \\
(6-100 \mathrm{~nm}) @ 46 \mathrm{~m}\end{array}$ \\
\hline MMSF & 39.317 & 86.417 & Wet Effulent Diffusion Denuder (WEDD) & {$\left[\mathrm{NH}_{3}\right] @ 32 \mathrm{~m}$} \\
\hline MMSF & 39.317 & 86.417 & $\begin{array}{l}2 \times \text { Condensation Particle Counter (CPC, TSI } \\
3781)\end{array}$ & $\begin{array}{l}\text { Total aerosol particle number concentra- } \\
\text { tions } \\
(>6 \mathrm{~nm}) @ 28 \text { and } 12 \mathrm{~m}\end{array}$ \\
\hline MMSF & 39.317 & 86.417 & Nano-MOUDI, MOUDI (MSP-110) & $\begin{array}{l}\text { Inorganic ions @ } 28 \mathrm{~m} \text { on } 14 \text { stages } \\
(10 \mathrm{~nm} \text { to } 18 \mu \mathrm{m})\end{array}$ \\
\hline MMSF & 39.317 & 86.417 & MOUDI (MSP-110) & $\begin{array}{l}\text { Organic ions@ } 28 \mathrm{~m} \text { on } 11 \text { stages } \\
(56 \mathrm{~nm} \text { to } 18 \mu \mathrm{m})\end{array}$ \\
\hline MMSF & 39.317 & 86.417 & Multi-sorbent tubes & VOC@ canopy (@approx.20m) \\
\hline MMSF & 39.317 & 86.417 & $\begin{array}{l}\text { Chemical Ionization Mass Spectrometer } \\
\text { (CIMS) }\end{array}$ & {$\left[\mathrm{H}_{2} \mathrm{SO}_{4}\right] @$ ground } \\
\hline MMSF & 39.317 & 86.417 & TECO monitor & {$\left[\mathrm{SO}_{2}\right] @$ ground } \\
\hline MMSF & 39.317 & 86.417 & Tethersonde & Meteorological profiles \\
\hline MMSF & 39.317 & 86.417 & Lidar (Natural Power ZephIR Lidar) & Meteorological profiles \\
\hline MMSF & 39.317 & 86.417 & Ceilometer (Vaisala CL31) & Mixed layer depth \\
\hline Air-strip & 39.252 & 86.502 & UAV w/CPC (3007) and GRIMM (1.109) & $\begin{array}{l}\text { Total aerosol particle number concentra- } \\
\text { tion } \\
(>10 \mathrm{~nm}) \text { and size distribution }(>250 \mathrm{~nm})\end{array}$ \\
\hline Bloomington & 39.171 & 86.506 & $\begin{array}{l}\text { Scanning Mobility Particle Sizer (SMPS TSI } \\
\text { 3936; EC3081, long-DMA, CPC3025A) }\end{array}$ & $\begin{array}{l}\text { Aerosol particle number size distributions } \\
(10-400 \mathrm{~nm}) @ 12 \mathrm{~m}\end{array}$ \\
\hline
\end{tabular}

lidar derived state parameters at Cabauw in the Netherlands also indicated that increased ultrafine aerosol particle number concentrations were observed in the residual layer between the growing boundary layer and freetroposphere (Stull, 1988). Further, these layers "were characterized by a sub-critical Richardson number and concomitant turbulence..." leading the authors to speculate that "turbulent mixing is likely to lead to local supersaturation of possible precursor gases... Observed peaks in the number concentrations of ultrafine aerosol particles at ground level are connected to the new aerosol particle formation in the residual layer by boundary layer development and vertical mixing." (Wehner et al., 2010). Thus during NIFTy we deployed a scanning doppler lidar system and tethersonde at MMSF to examine vertical profiles of meteorological conditions in addition to analyzing data from ongoing micrometeorological and ceilometer measurements (Table 1).

3. To examine associations between organic and inorganic gas concentrations and ultra-fine aerosol particle composition and number concentration during nucleation events. The precise mechanism for nucleation remains uncertain, and the relative importance of binary, ternary and ion-induced nucleation likely vary in space and time (Gagné et al., 2010), but likely most nucleation events involve sulfuric acid (Nieminen et al., 2009; Sipila et al., 2010; Weber et al., 2001; Weber et al., 1997), ammonia (Korhonen et al., 1999; Napari et al., 2002) and/or organics (Metzger et al., 2010; Zhang et al., 2004b), or some combination thereof (Paasonen et al., 2010). Subsequent growth of the freshly formed aerosol particles occurs via multi-component condensation and to a smaller extent by coagulation (Boy et al., 2005; Stolzenburg et al., 2005; Wehner et al., 2005). Particle growth in locales with high sulfur dioxide emissions is dominated by sulfuric acid (Petäjä et al., 2007; Sakurai et al., 2005; Stolzenburg et al., 2005). Generally in less polluted regions particle growth is dominated by compounds other than sulfuric acid (Boy et al., 2005; Wehner et al., 2005), and there is evidence for a role of organics (particularly biogenics) in aerosol particle formation and initial growth in forested locations (Metzger et al., 2010; Place et al., 2010). Indiana, and indeed the whole Midwestern USA, is characterized by very high emissions of the precursors of ternary nucleation $\left(\mathrm{SO}_{2}\right.$ (and thus sulfuric acid $\left.\left(\mathrm{H}_{2} \mathrm{SO}_{4}\right)\right)$ and ammonia 
$\left.\left(\mathrm{NH}_{3}\right)\right)$. Accordingly, prior research using an aerosol mass spectrometer in Pittsburgh (east of the Ohio River Valley) showed that, during nucleation events, aerosol particles with physical diameters of 18 to $33 \mathrm{~nm}$ showed an initial increase in sulfate $\left(\mathrm{SO}_{4}^{2-}\right)$ concentrations followed by increased ammonium $\left(\mathrm{NH}_{4}^{+}\right)$concentrations (delayed by $10-40 \mathrm{~min}$ ) and ultimately an increase in oxygenated organics (Zhang et al., 2004a), thus indicating a dominant role for the inorganic gases in the initial aerosol particle formation and growth at this location. Equally measurements during Border Air Quality and Meteorology Study (BAQS-Met 2007) conducted to the north of Indiana exhibited a high degree of association between sulfur dioxide $\left(\mathrm{SO}_{2}\right)$ concentrations and nucleation occurrence (Jeong et al., 2010). To examine the chemistry of ultra-fine aerosol particle concentrations and links to gas phase chemistry during NIFTy continuous measurements of $\mathrm{SO}_{2}, \mathrm{NH}_{3}, \mathrm{H}_{2} \mathrm{SO}_{4}$ and timeaveraged VOC and aerosol particle composition were made at the MMSF site (Table 1).

\section{Experimental design and methods}

\subsection{Sampling sites}

Measurements presented herein were conducted along an $80 \mathrm{~km}$ transect from the small town of Bloomington in the southwest, to northeastern Indianapolis to the northeast. The transect (Fig. 1) has at its approximate mid-point the long-term aerosol particle measurement site in the MorganMonroe State Forest (MMSF) (39 $19^{\prime} \mathrm{N}, 86^{\circ} 25^{\prime} \mathrm{W}$, Fig. 1). MMSF is an extensive broad-leafed forest with a total area of over $95.3 \mathrm{~km}^{2}$. The single-sided leaf area index (LAI) of the forest during the experiment was approximately $4 \mathrm{~m}^{2} \mathrm{~m}^{-2}$, and tree total basal area is approximately $26 \mathrm{~m}^{2} \mathrm{ha}^{-1}$. The forest is dominated by five species: sugar maple (Acer saccharum, 27\%), tulip poplar (Liriodendron tulipifera, 19\%), sassafras (Sassafras albidum, 9.5\%), white oak (Quercus alba, 9\%), and black oak (Quercus nigra, 8.5\%). Bloomington (on the southwest end of the transect) is a small college town (population approximately 80000 ), while Indianapolis is the fifth most populous city in the USA (population of 6.5 million) and currently fails current ozone and particulate matter air quality standards (Pryor and Spaulding, 2009). The sampling site used herein is located approximately $5 \mathrm{~km}$ downwind of the urban core.

\subsection{Instrumentation}

\subsubsection{Aerosol physical characterization}

Aerosol particle size distributions have been continuously measured at MMSF since December 2006 using two Scanning Mobility Particle Sizer (SMPS) systems from TSI Inc.
A Fast Mobility Particle Sizer (FMPS 3091) (TSI, Inc) (Tammet et al., 2002) was added in November 2007. During NIFTy the SMPS system comprising an Electrostatic Classifier (Model 3080), long-DMA (Model 3081), and a Condensation Particle Counter (CPC) (Model 3025A) was redeployed to the Bloomington site. The second SMPS comprising an Electrostatic Classifier (Model 3080), nano-DMA (Model 3085), and a Condensation Particle Counter (Model 3786) and a FMPS were operated at MMSF sampling from a height of $46 \mathrm{~m}$ (the forest canopy is at 26-28 m). A fourth particle sizing system - a FMPS was operated in northeast Indianapolis at an Indiana Department of Environmental Management air quality site (see Table 1).

For the flow rates and inlet nozzles used herein the aerosol particle size range reported by the SMPS operated in Bloomington is 9.8 to $414.2 \mathrm{~nm}$, while for the SMPS operated at MMSF it is 3.22 to $105.5 \mathrm{~nm}$. However, the long sampling tube used at MMSF functionally limits the sampling range to above $6 \mathrm{~nm}$, since this is the minimum aerosol particle diameter $(D p)$ for which transmission efficiencies exceed 10\%. In both cases the SMPS systems were deployed with the multiple charge and diffusion loss corrections in the AIM software turned on (Frank et al., 2008). The aerosol particle size resolved concentrations from the SMPS and FMPS deployed at MMSF were corrected for tubing losses computed using experimentally derived correction factors (Pryor et al., 2010). The FMPS systems used at MMSF and Indianapolis measure aerosol particle concentrations in 32 equally spaced (logarithmic scale) size channels from 6.04 to $523.3 \mathrm{~nm}$ but the sampling inlet used in Indianapolis limited the diameter range for which reliable data were collected to $10-200 \mathrm{~nm}$.

Inter-comparison of aerosol particle sizing instruments used at the different sites during NIFTy indicates relatively good correspondence from three of the instruments - the SMPS system deployed in Bloomington and the FMPS and SMPS deployed at MMSF. As in prior research sub-30nm aerosol particle concentrations are slightly lower from the FMPS (Jeong and Evans, 2009), while concentrations of approximately $100 \mathrm{~nm}$ diameter particles are higher in both FMPS systems (Asbach et al., 2009). Size distributions from the FMPS deployed in Indianapolis differ substantially from those derived from the other instruments (Fig. 2). This discrepancy may derive from noise on the electrometers (specifically mis-counting aerosol particles at smaller sizes with the FMPS due to residue on the electrometer stages), or slight mis-alignment in the aerosol flow within the FMPS deployed in Indianapolis. In light of this discrepancy, the aerosol particle size distributions from Indianapolis must be viewed with caution, and growth rates computed there from are deemed too uncertain to present herein.

To examine the vertical extent of the layer through which enhanced ultra-fine aerosol particle concentrations are observed an instrumented UAV was flown from a private airstrip approximately $10 \mathrm{~km} \mathrm{SW}$ of the MMSF tower. The UAV was flown in a pattern of displaced spirals to avoid 


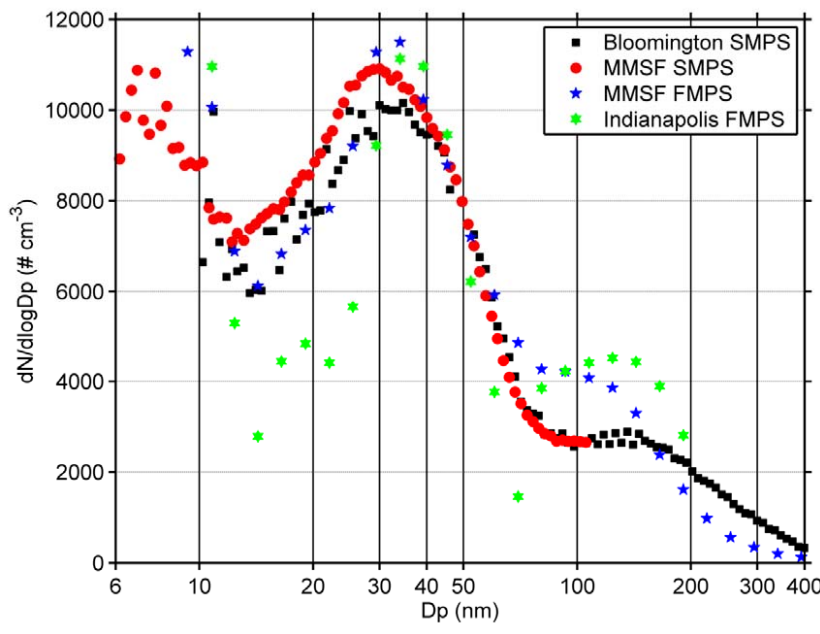

Fig. 2. Comparison of aerosol particle number size distributions over a four hour period from the four sizing instruments deployed during NIFTy. The data derive from an instrument inter-comparison conducted at MMSF.

sample contamination from the engine. Vertical profiles up to a maximum height of $300 \mathrm{~m}$ a.g.l. of total ultrafine aerosol particle concentrations and size distributions were measured using a CPC (TSI 3007) and GRIMM Portable Aerosol Spectrometer (1.109, from Grimm Aerosol technik GmbH) (Table 1).

\subsubsection{Aerosol chemical characterization}

An MSP MOUDI-110 with nano-MOUDI attachment was installed at the MMSF tower at $28 \mathrm{~m}$ and operated to measure $24 \mathrm{~h}$ average inorganic ion concentrations. Nominal cut points for the MOUDI-110 (for 30 liters per minute (l.p.m.) flow rate) are; 18, 10, 5.6, 3.2, 1.8, 1.0, 0.56, 0.32, 0.18, 0.1, and $0.056 \mu \mathrm{m}$, while the nano-MOUDI nominal cut points are; 32,18 and $10 \mathrm{~nm}$. Aluminum foil substrates, coated using silicon spray to minimize aerosol particle bounce, were used for analysis of inorganic ions. After collection the foils were immediately placed in test-tubes and extracted for two hours in oxalic acid $\left(10^{-5} \mathrm{M}\right)$ on a stirring table, and then analyzed on an ion chromatograph (IC, DIONEX DX-120). The ions for which standards were applied to the IC and for which observed concentrations in any sample exceeded the minimum detection limits (MDL) were; sodium $\left(\mathrm{Na}^{+}\right)$, ammonium $\left(\mathrm{NH}_{4}^{+}\right)$, potassium $\left(\mathrm{K}^{+}\right)$, magnesium $\left(\mathrm{Mg}^{2+}\right)$, calcium $\left(\mathrm{Ca}^{2+}\right)$, chloride $\left(\mathrm{Cl}^{-}\right)$, nitrate $\left(\mathrm{NO}_{3}^{-}\right)$, phosphate $\left(\mathrm{PO}_{4}^{3-}\right)$ and sulfate $\left(\mathrm{SO}_{4}^{2-}\right)$. Uncertainty bounds and MDL for the ion concentrations reported herein were computed based on replica analysis of standards (spanning the range of concentrations in the ambient samples) on the IC. Repeat extractions of ten randomly selected MOUDI foils did not show any ion concentrations above the MDL, indicating complete extraction of the sample by the aforementioned procedure.
A second MOUDI-110 was operated with quartz filters for capture and analysis of organics, but due to difficulties with the filter extractions no data are reported from that system.

\subsubsection{Gas phase characterization}

One minute average $\mathrm{NH}_{3}$ concentrations were made at $32 \mathrm{~m}$ using a Wet Effluent Diffusion Denuder (WEDD) system (Pryor et al., 2001), while the 30-min average concentrations of $\mathrm{SO}_{2}$ and $\mathrm{H}_{2} \mathrm{SO}_{4}$ close to ground level reported herein were made with a TECO (Model 43S) monitor and a Chemical Ionization Mass Spectrometer (CIMS) (Eisele and Tanner, 1993; Mauldin III et al., 2003), respectively. A limited number of hydroxyl radical $(\mathrm{OH})$ measurements were also made with the CIMS (Berresheim et al., 2000; Eisele and Tanner, 1993; Mauldin III et al., 2003).

VOC concentrations were measured in six approximately 2-h intervals starting 09:00 (LST) at a flow rate of $27 \mathrm{ml} \mathrm{min}^{-1}$ on multi-sorbent cartridges (MSC), following EPA Method TO-17. Samples were analyzed for the following indicators of biogenic VOCs; isoprene, $\alpha$-pinene, limonene, cumene (isopropylbenzene), and for the following indicators of anthropogenic VOCs; benzene, toluene, ethyl benzene, o-, m-, and p-xylene. The resulting VOC concentrations are used herein to provide a first-order assessment of the production of low-volatility oxidation products using Fractional Aerosol Coefficients (FAC) (Grosjean, 1992) (see Supplement).

\subsubsection{Meteorological instrumentation}

To supplement the ongoing micro-meteorological and ceilometer (Vaisala CL31) measurements that are continuously made at the MMSF tower as part of the AmeriFlux network protocols, detailed meteorological profiles were obtained in a small clearing close to the MMSF tower using a scanning doppler lidar (Natural Power ZephIR lidar) and a Vaisala tethersonde system equipped with a temperature, humidity and wind package. The Natural Power ZephIR is a ground-based doppler lidar system designed to accurately measure horizontal and vertical wind speed, wind direction and turbulence up to $300 \mathrm{~m}$ height. The lidar measures in a cone of $30^{\circ}$ from the vertical enabling horizontal and vertical components of the wind speed to be determined from the radial velocity (Wagner et al., 2009). In effect the characteristics of a volume of air are measured from a conical scan pattern as the beam is moved and focused by a lens at different heights (Emeis et al., 2008). Each measurement takes about $20 \mathrm{~ms}$ enabling multiple sampling at one height and a full scan at each of the measurement heights in $3 \mathrm{~s}$. The turbulence parameter is a slightly different metric of turbulence than is obtained using a cup or sonic anemometer in that it represents the turbulence intensity of the radial wind speed within the scanned circles, however it shows good 
correspondence with turbulence metrics from anemometers (Wagner et al., 2009).

\subsection{Methods}

\subsubsection{Model description}

Vertical profiling of the aerosol particle number concentrations with the UAV coupled with the number size distributions determined at the MMSF tower site enabled us to probe aerosol particle number concentration budgets in the boundary layer. The measured concentrations were used as input values for a box model applied assuming the layer is wellmixed and that the event was regionally coherent in character (allowing us to neglect the role of advection), to assess the relative importance of coagulation, dry deposition and entrainment/dilution due to growth of the boundary layer. Aerosol particle coagulation within the model was computed using COAGSOLV, a semi-implicit aerosol particle coagulation solver (Jacobson et al., 1994), while dry deposition was calculated using the size-dependent deposition velocities for MMSF (Pryor et al., 2009). We further obtain an estimate of the degree to which the model estimates are reasonable by inverting this analysis. We apply a simple budget model to assess what the entrainment velocity would need to be if the source strength for ultrafine aerosol particles with diameters below $30 \mathrm{~nm}$ was zero, and the concentration of ultrafine aerosol particles with diameters below $30 \mathrm{~nm}$ was zero above the mixed layer. Thus the following budget equation was applied (Fairall and Larsen, 1984):

$$
\left(\frac{1}{C(D p)} \frac{d C(D p)}{d t}\right) h+v_{d}(D p)=w_{e}
$$

\section{Where}

$C(D p)$ is the concentration of aerosol particles in a size range $(D p=10-30 \mathrm{~nm})$

$d C(D p)) / d t=$ the rate of change of concentration (corrected for coagulation losses computed as described above)

$h=$ mixed layer depth (estimated from the ceilometers backscatter data)

$v_{d}(D p)=$ the mean dry deposition velocity for aerosol particles of 10 to $30 \mathrm{~nm}$ (Pryor et al., 2009).

$w_{e}=$ entrainment velocity

\subsubsection{Nucleation metrics}

Data from all four aerosol particle sizing instruments operated during NIFTy were analyzed to determine event frequency and characteristics based on a subjective classification protocol (Boy and Kulmala, 2002; Dal Maso et al., 2005) (see Supplement). The condensational sink (CS) was computed from these data assuming the condensing vapors have a very low vapor pressure, an accommodation coefficient of 1, and exhibit properties similar to sulfuric acid (Kulmala et al., 2001). From the data collected at MMSF we additionally calculated a modified version of Boy and Kulmala's (2002) "nucleation parameter" (NP):

$\mathrm{NP}=\frac{\mathrm{UV}}{\left[\mathrm{H}_{2} \mathrm{O}\right] \times T}$

Where:

UV is derived from measurements $46 \mathrm{~m}$ of short-wave incoming solar radiation (as measured using a LI-COR LI-200SZ-50 pyranometer)

$\left[\mathrm{H}_{2} \mathrm{O}\right]=$ water vapor concentration (in molecules $\mathrm{m}^{-3}$ ) (as measured using a Meteolabor AG, VTP37 thermohygrometer)

$T=$ air temperature $(\mathrm{K})$ from the Meteolabor AG, VTP37 thermohygrometer.

We also computed the dimensionless nucleation parameter $\left(L_{\Gamma}\right)$ proposed by Kuang et al. (2010):

$L_{\Gamma}=\frac{\overline{c_{1}} A_{\text {Fuchs }}}{4 \Gamma \beta_{11} N_{m}}$

Where:

$\overline{c_{1}}=$ mean thermal speed for a $3-\mathrm{nm}$ hydrated $\mathrm{H}_{2} \mathrm{SO}_{4}$ (taken here as $\approx 2 \times 10^{3} \mathrm{~cm} \mathrm{~s}^{-1}$, (Weber et al., 1997))

$A_{\text {Fuchs }}=$ Fuchs surface area (McMurry et al., 2005)

$\Gamma=$ Growth enrichment factor (Kuang et al., 2010)

$\beta_{11}=$ monomer-monomer coagulation coefficient (computed assuming the monomer is hydrated $\mathrm{H}_{2} \mathrm{SO}_{4}$ (McMurry et al., 2005))

$N_{m}$ = peak value of $\left[\mathrm{H}_{2} \mathrm{SO}_{4}\right]$. Herein we use half-hourly average measured values from the CIMS, and note that they were observed below the tree canopy thus, they may underestimate above-canopy concentrations.

This parameter $\left(L_{\Gamma}\right)$ characterizes the ratio of particle scavenging loss to growth rate, and a value of 0.7 was shown based on data from 27 nucleation event days and 19 nonevent days during five previous intensive field experiments to indicate a threshold above which nucleation is suppressed (Kuang et al., 2010). 

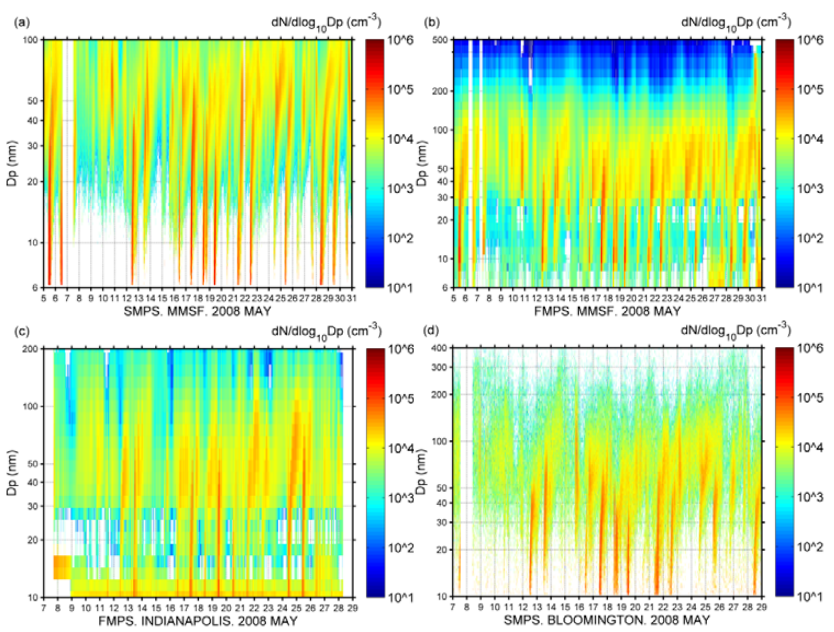

Fig. 3. Time series of size-resolved aerosol particle number concentrations during NIFTy based on data from the (a) SMPS and (b) FMPS deployed at MMSF, (c) FMPS at Indianapolis, and (d) SMPS in Bloomington. Note the time periods shown differ slightly by site, and the aerosol particle diameter range shown varies according to the detection limits of the instrument used.

\section{Results and discussion}

\subsection{Spatial scales of nucleation}

\subsubsection{Horizontal profiles along the NIFTy transect}

In keeping with the prior climatology of ultrafine aerosol particle concentrations at MMSF (Pryor et al., 2010), high concentrations of ultrafine aerosol particles with a diameter below $20 \mathrm{~nm}$ and clear growth were observed on multiple days during the NIFTy experiment (Table 2 and Fig. 3). While division of the data between the three event classes and non-events is subjective, independent classifications for measurements at the three sites show a relatively high degree of coherence. Of the days when there is evidence for class A nucleation events at MMSF and for which measurements are also available from Indianapolis and Bloomington, measurements at all three sites indicated a significant increase in ultrafine aerosol particle concentrations, though on two days the event classification for the other two sites (Indianapolis and Bloomington) indicated $\mathrm{C}$ rather than A class events.

Growth rates (GR) computed from the number geometric mean diameter (nGMD) for $D p=6-30 \mathrm{~nm}$ based on data from the SMPS at MMSF for the A-events had a mean value of $3.6 \mathrm{~nm} \mathrm{hr}^{-1}$, and ranged from a minimum of $2.0 \mathrm{~nm} \mathrm{hr}^{-1}$ to a maximum of $5.4 \mathrm{~nm} \mathrm{hr}^{-1}$. These values are in agreement with typical values obtained elsewhere (Kulmala et al., 2004), and are very similar to GR computed from nGMD for $D p=10-40 \mathrm{~nm}$ based on data from the SMPS in Bloomington for the A-events (mean value of $3 \mathrm{~nm} \mathrm{hr}^{-1}$, range of 2.3 to $4.9 \mathrm{~nm} \mathrm{hr}^{-1}$ ). Given the discrepancy in the exact size range used to compute GR, these results indicate the two sites ex-
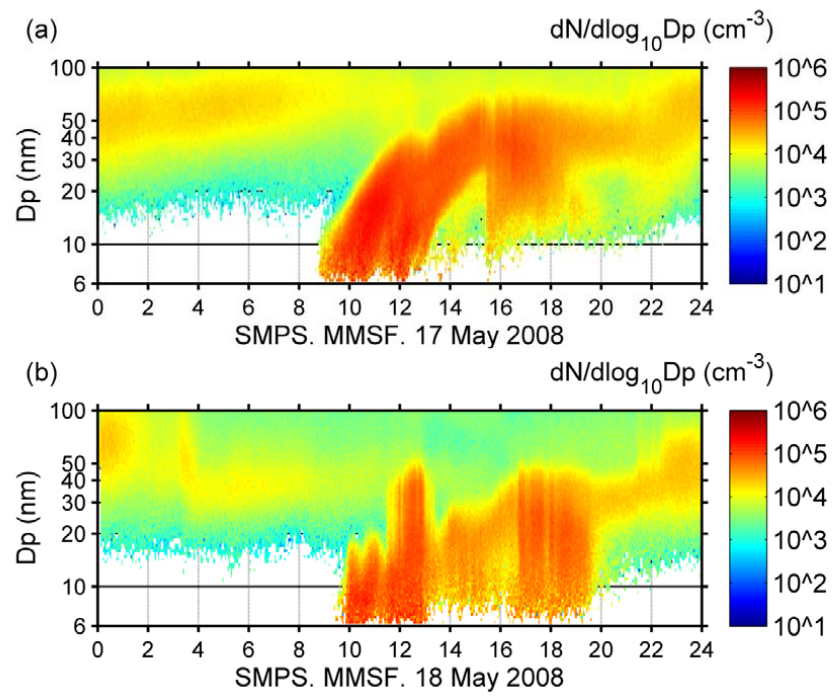

Fig. 4. Time series of size-resolved aerosol particle number concentrations $\left(d N / d \log _{10} D p\right)$ at MMSF based on data derived from the SMPS on (a) 17 May 2008 and (b) 18 May 2008.

hibited very similar growth rates. This may imply that the nucleation events are both regional in occurrence and regionally homogeneous in terms of the subsequent aerosol particle growth.

\subsubsection{Case studies of double-peak event days}

On two days (17 and 18 May), data from all three sites show evidence for a double peak in ultrafine aerosol particle concentrations, wherein an initial increase in aerosol particle number concentrations was observed followed by a decline in number concentrations, and then a second burst of ultrafine aerosol particles (see Fig. 4). In common with other days on which nucleation was observed, the initial aerosol particle number concentration increase was preceded by an increase in turbulence (as manifest by an increase in the momentum flux in see Fig. S1, and discussion of the turbulence data from the lidar given below). The increase in turbulence was associated with an increase in incoming solar radiation and an increase in both $\mathrm{H}_{2} \mathrm{SO}_{4}$ and $\mathrm{SO}_{2}$ concentrations, consistent with the postulate that entrainment is strongly coupled to aerosol particle nucleation. On 17 May the initial increase in aerosol particle number concentrations was associated with a small decrease in $\mathrm{NH}_{3}$ concentrations possibly as a result of $\mathrm{NH}_{3}$ consumption in aerosol particle nucleation and growth. On both days the second increase in ultrafine aerosol particle number concentrations was associated with a second peak in solar radiation after a period of increased cloud cover as recorded by the ceilometer. The observed increase in $\mathrm{H}_{2} \mathrm{SO}_{4}$ and $\mathrm{SO}_{2}$ followed an increase in turbulent activity and increased solar flux and thus may be due to renewed mixed layer growth and entrainment, and/or possibly enhanced photochemistry and production of $\mathrm{H}_{2} \mathrm{SO}_{4}$. 
Table 2. Summary of the event days based on the classification of Boy and Kulmala (2002) and the start time of the event as derived from data obtained using aerosol particle sizing instrumentation deployed at MMSF, Indianapolis and Bloomington during NIFTy. N/A denotes periods when the instrument was not operating at the specified site for that day. To allow comparison across the sites the start hour denotes the hour in which the maximum increase in the number concentration of $10 \mathrm{~nm}$ diameter aerosol particles was first noted. For event class B a threshold diameter of $20 \mathrm{~nm}$ is used.

\begin{tabular}{|c|c|c|c|c|c|c|c|c|}
\hline \multirow[t]{2}{*}{ Day of Month } & \multicolumn{2}{|c|}{ Bloomington SMPS } & \multicolumn{2}{|c|}{ MMSF SMPS } & \multicolumn{2}{|c|}{ MMSF FMPS } & \multicolumn{2}{|c|}{ Indianapolis FMPS } \\
\hline & Event type & Start hour (LST) & Event type & Start hour (LST) & Event type & Start hour (LST) & Event type & Start hour (LST) \\
\hline 5 & N/A & N/A & A & 9 & A & 9 & N/A & N/A \\
\hline 6 & $\mathrm{C}$ & N/A & $\mathrm{C}$ & 10 & $\mathrm{C}$ & N/A & N/A & N/A \\
\hline 12 & A & 11 & A (double event) & 10 & A & 10 & A & 10 \\
\hline 13 & $\mathrm{~B}$ & 11 & B & 11 & B & 11 & $\mathrm{C}$ & 9 \\
\hline 16 & $\mathrm{C}$ & 10 & $\mathrm{C}$ & 9 & $\mathrm{C}$ & 9 & $\mathrm{C}$ & 10 \\
\hline 17 & A (double event) & 10 & A (double event) & 9 & A & 9 & A (double event) & 9 \\
\hline 18 & $\mathrm{C}$ & 11 & $\mathrm{C}$ & 10 & $\mathrm{C}$ & 10 & $\mathrm{C}$ & 10 \\
\hline 19 & $\mathrm{C}$ & 10 & A & 9 & $\mathrm{~A}$ & 9 & A & 9 \\
\hline 20 & None & N/A & B & 13 & $\mathrm{~B}$ & 13 & $\mathrm{C}$ & 10 \\
\hline 21 & A & 8 & A & 8 & A & 8 & A & 10 \\
\hline 22 & A & 11 & A & 9 & A & 9 & A & 12 \\
\hline 24 & A & 12 & A & 10 & A & 10 & $\mathrm{~A}$ & 9 \\
\hline 25 & $\mathrm{C}$ & 12 & A & 9 & $\mathrm{C}$ & 9 & $\mathrm{C}$ & 9 \\
\hline 28 & A & 10 & A & 8 & A & 8 & N/A & N/A \\
\hline
\end{tabular}
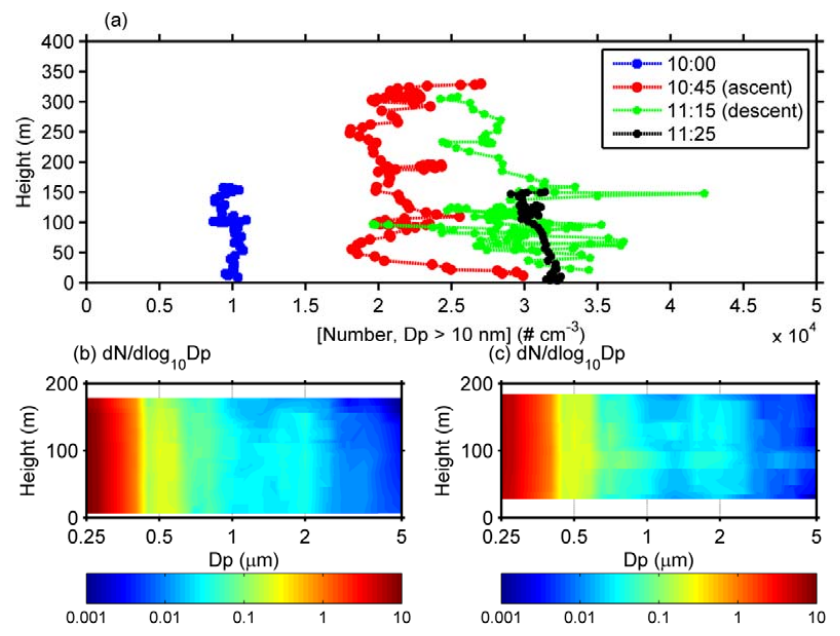

Fig. 5. (a) Profiles of total aerosol particle concentrations $(D p \geq 10 \mathrm{~nm})$ from the CPC on board the UAV on 22 May. The legend shows the time (in LST) at which the profile was taken. The lower frames (b) and (c) show vertically discretized size-resolved aerosol particle concentrations $\left(d N / d \log _{10} D p\right)$ as measured with the GRIMM on the UAV on 22 May 2008 at (b) 10:00 and (c) 11:25 (LST).

\subsubsection{Vertical profiles of ultrafine aerosol particle concentrations}

One example of data collected on UAV flights prior to and following initiation of a nucleation event on 22 May is shown in Fig. 5. Vertical profiles of total aerosol particle concentrations for $D p \geq 10 \mathrm{~nm}$ prior to initiation of the event at MMSF (see Fig. 6), indicate a well-mixed layer with fairly homogeneous aerosol particle number concentrations of $1 \times 10^{4} \mathrm{~cm}^{-3}$ at approximately 10:00 LST. As the event was
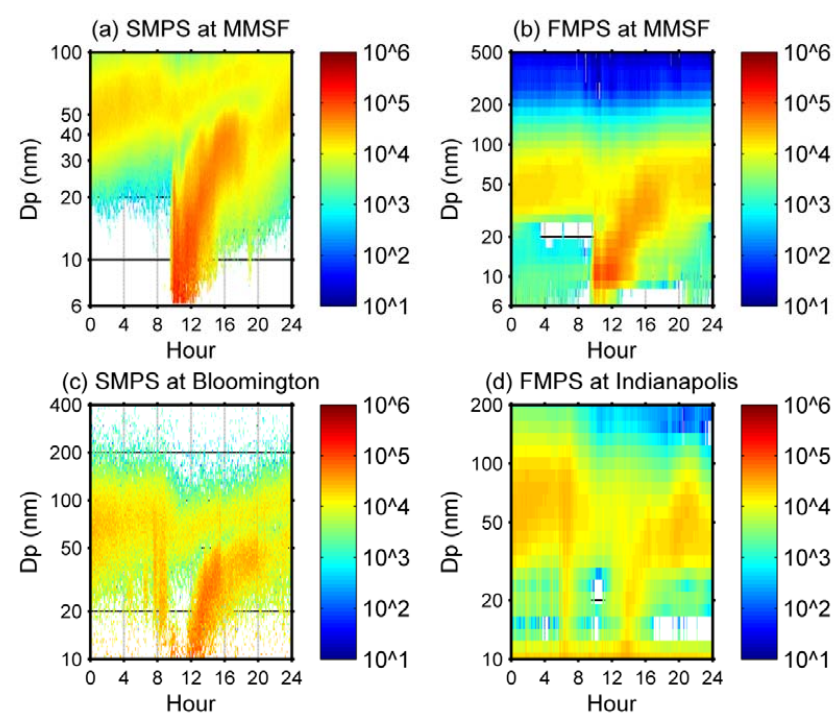

Fig. 6. Size resolved aerosol particle number concentrations $\left(d N / d \log _{10} D p\right)$ on 22 May 2008 as measured using the (a) SMPS and (b) FMPS at MMSF, (c) SMPS at Bloomington, and (d) FMPS at Indianapolis.

observed at MMSF, the vertical profile showed a substantial increase in total aerosol particle number concentrations and significant vertical structure. Within two hours of event initiation, the vertical profile of aerosol particle concentrations was well-mixed to a height of over $300 \mathrm{~m}$. The homogenization of aerosol particle number concentrations over less than $30 \mathrm{~min}$ is consistent with time scale analysis for the mixed layer. Assuming the mixed layer depth $(z)$ derived from the ceilometer backscatter density gradients for 10:3011:00 (LST) of $800 \mathrm{~m}$, and an average energy dissipation rate 
$(\varepsilon)$ deriving from the synthesis of data from the tethersonde, lidar and sonic anemometer at $46 \mathrm{~m}$, of $5 \times 10^{-3} \mathrm{~m}^{2} \mathrm{~s}^{-3}$, the mixing time scale $\left(\tau_{\text {mix }}, \tau_{\text {mix }}=\left(\frac{z^{2}}{\varepsilon}\right)^{1 / 3}\right.$ (Kaimal and Finnigan, 1994; Wehner et al., 2010) is approximately $500 \mathrm{~s}$ (about $9 \mathrm{~min})$. Little vertical structure is evident in the super- $250 \mathrm{~nm}$ aerosol particle concentrations from the GRIMM deployed on the UAV during any of the flights on this day (Fig. 5), implying the structure in the ultrafine particle concentrations is due to in situ production rather than horizontal advection. During about a $90 \mathrm{~min}$ period the total aerosol particle number concentrations $(D p \geq 10 \mathrm{~nm})$ throughout a layer of at least $300 \mathrm{~m}$ increased by a factor of over three (from approximately $1 \times 10^{4} \mathrm{~cm}^{-3}$ to $3.2 \times 10^{4} \mathrm{~cm}^{-3}$, Fig. 5). This is consistent with SMPS data from the MMSF tower which showed an increase in total aerosol particle number concentrations of a factor of four for $D p \geq 10 \mathrm{~nm}$. The magnitude of increases in ultrafine aerosol particle concentrations observed on 22 May provides some indirect validation of the modeling conducted using PMCAMx-UF based on ternary nucleation which indicated the increase in $\geq 10 \mathrm{~nm}$ aerosol particle number concentrations during nucleation events was approximately $2 \times 10^{4} \mathrm{~cm}^{-3}$ (Jung et al., 2010).

\subsubsection{Atmospheric fate of recently produced ultrafine aerosol particles}

The instrumented UAV was also flown subsequent to the initial phases of nucleation events to examine the subsequent fate of recently formed aerosol particles and the evolution of vertical concentration profiles. On 17 May 2008, the UAV was flown (take-off at 13:52 LST), about one hour after termination of the period with highest $6 \mathrm{~nm}$ aerosol particle concentrations at MMSF (Fig. 7a). Total aerosol particle number concentrations $(D p \geq 10 \mathrm{~nm})$ over a $250 \mathrm{~m}$ layer were calculated for the first $15 \mathrm{~min}$ and last $15 \mathrm{~min}$ of the flight. The results indicate total aerosol particle number concentrations decreased from an average of $3.96 \times 10^{4} \mathrm{~cm}^{-3}$ to $3.28 \times 10^{4} \mathrm{~cm}^{-3}$ over the course of $30 \mathrm{~min}$. We initialized the box model by applying the size distribution as measured using the SMPS at MMSF to the UAV total aerosol particle concentrations and then ran the model for $30 \mathrm{~min}$. The results indicate coagulation accounts for approximately half of the number concentration reduction (i.e. a aerosol particle number concentration decrease of $3600 \mathrm{~cm}^{-3}$ ), dry deposition accounts for a number concentration reduction of approximately $1800 \mathrm{~cm}^{-3}$, and thus the residual of approximately $1600 \mathrm{~cm}^{-3}$ is assumed to be due to entrainment/dilution. Based on (1), this aerosol budget analysis indicates an entrainment velocity of $7 \mathrm{~cm} \mathrm{~s}^{-1}$ (computed assuming zero ultrafine aerosol particle concentrations above the mixed layer) which shows good agreement with the lidar estimate of mean vertical velocities (in the period 14:00 to $14: 30$ at $300 \mathrm{~m}$ ) of $-8 \mathrm{~cm} \mathrm{~s}^{-1}$ (where the negative number indicates a downwards vertical velocity). While typical entrainment velocities
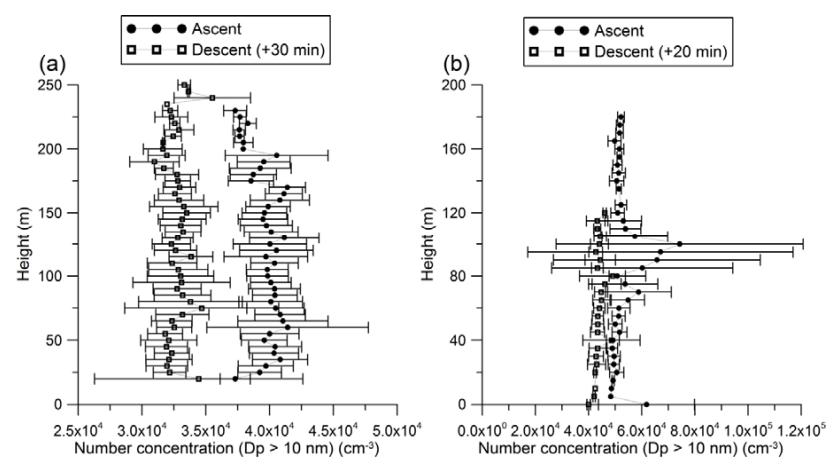

Fig. 7. Vertical profiles of total aerosol particle number concentrations $(D p \geq 10 \mathrm{~nm})\left(\mathrm{cm}^{-3}\right)$ from the UAV on (a) 17 May 2008 and (b) 19 May 2008. The profile from the ascent flight on 17 May was derived as the average profiles from the first $15 \mathrm{~min}$ of the flight which took off at 13:52, while the descent profile is the average of profiles obtained $30 \mathrm{~min}$ later over a $15 \mathrm{~min}$ period. The profile from the ascent flight on 19 May was derived as the average profiles from the first $10 \mathrm{~min}$ of the flight which took off at 12:40, while the descent profile is the average of profiles obtained approximately $20 \mathrm{~min}$ later over a $10 \mathrm{~min}$ period. In each frame the horizontal bars show the standard deviation of the $1 \mathrm{~s}$ measurements at each height.

over water are generally less than $1 \mathrm{~cm} \mathrm{~s}^{-1}$ (Lenschow et al., 1999), larger entrainment rates are likely over land (Batchvarova and Gryning, 1994), and thus the derived entrainment velocity is reasonable, and the box model analysis appears valid.

To test the budget estimates from 17 May, a second analysis was conducted for the flight on 19 May which again was initiated just shortly after termination of nucleation. Although the aerosol particle number concentration profile in the ascent portion of the flight exhibited more variability than on 17 May (notably associated with higher number concentration variability centered at about $100 \mathrm{~m}$ elevation, Fig. 7b), the results are similar to those for 17 May in terms of the relative importance of the aerosol particle loss processes. For 19 May the box model analysis indicates coagulation again accounts for approximately half of the number concentration reduction (i.e. a number concentration decrease of $3300 \mathrm{~cm}^{-3}$ ), dry deposition accounts for a number concentration reduction of approximately $1600 \mathrm{~cm}^{-3}$, and thus entrainment/dilution (i.e. the residual) accounts for a aerosol particle number concentration reduction of approximately $1900 \mathrm{~cm}^{-3}$. However, these estimates are subject to higher uncertainty than for the 17 May because scattered precipitation was observed in the region at the time of the UAV flight on 19 May.

\subsection{Meteorology during nucleation events}

Synoptic regimes in the Midwestern USA are extremely dynamic during the springtime and accordingly the NIFTy experiment was characterized by the passage of a number of 

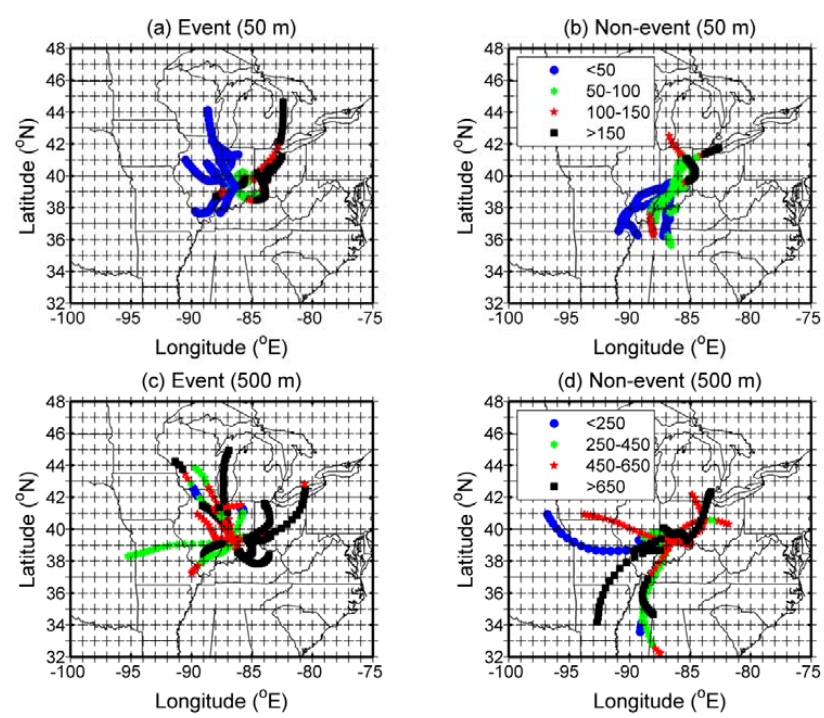

Fig. 8. The height a.g.l. of back trajectories terminating at MMSF at a height of $50 \mathrm{~m}$ and $500 \mathrm{~m}$ on event and non-event days during the NIFTy field experiment (5-31 May, 2008). These 24-h back trajectories were computed using the HYSPLIT trajectory model (run online at http://ready.arl.noaa.gov/HYSPLIT_traj.php) with the meteorological data provided by the EDAS (North American Model (Eta) Data Assimilation System) model output at $40 \mathrm{~km}$. The backtrajectory was initialized at the receptor site (MMSF) at 12:00 (LST) from a receptor height of 50 and $500 \mathrm{~m}$ about the ground surface.

fronts associated with transitory mid-latitude cyclones interspersed with days on which anticyclonic conditions dominated. This variability is manifest in the back trajectories that terminated at MMSF at 50 and $500 \mathrm{~m}$ a.g.l. However, as in Pryor et al. (2010) there is something of a tendency towards a greater prevalence of northerly flow on the days on which evidence of nucleation was observed at MMSF (Fig. 8) consistent with cold front passages from the north and northwest.

A much clearer dependence on local meteorological parameters is apparent. The principal difference between nonevent days during NIFTy and days with $\mathrm{A}$ and B or C events is the presence of cloud cover (as diagnosed from the ceilometer back-scatter data) particularly during the hours after sunrise. A-events were only observed on days when fractional cloud cover between 06:00 and 12:00 (LST) was below 0.3. B and $\mathrm{C}$ events occurred on days with less than $60 \%$ cloud cover, while the non-event days exhibited almost total cloud cover during the morning hours (Fig. 9).

Based on data from the doppler lidar, there is also a clear link between initiation of nucleation events (i.e. the start of the period when high concentrations of $6 \mathrm{~nm}$ aerosol particles is observed at MMSF) and erosion of the stable nocturnal boundary layer. A composite of lidar derived wind speeds, turbulence intensity and vertical velocities for all event class A days indicates a clear transition from a strongly stratified

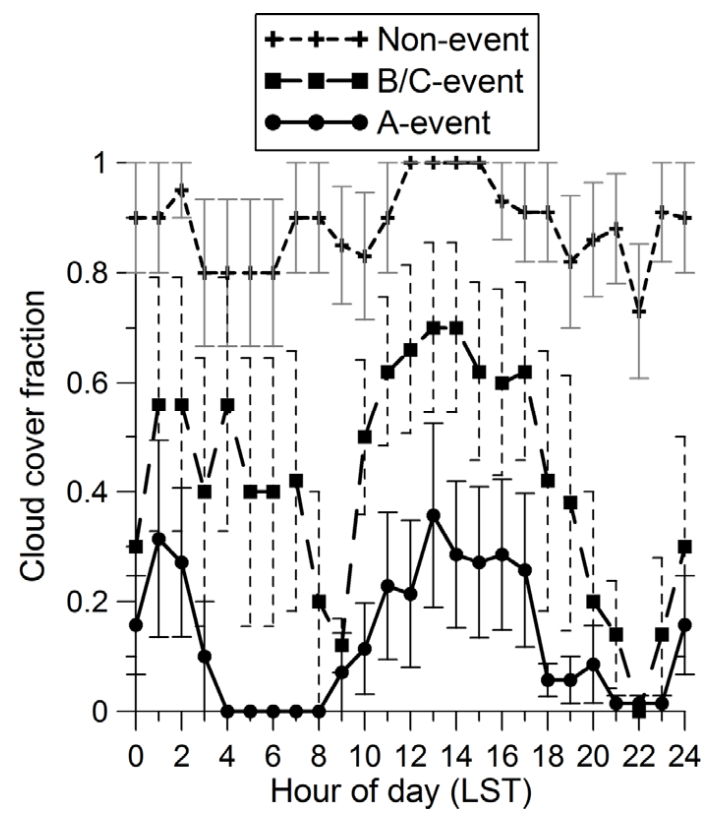

Fig. 9. Diurnal profiles of mean (and \pm 1 standard error) cloud cover on event days (class A and B and C) and non-event days during NIFTy. The cloud cover estimates derive from analysis of backscatter signals from the ceilometer.

atmosphere (with substantial increase in wind speed with height), low turbulence intensity and weak vertical velocities, to much a weaker vertical gradient of wind speed, increased turbulence intensity and stronger downwards vertical velocities, consistent with growth of the mixed layer and entrainment of air from the residual layer (Fig. 10). This transition occurs on average one hour prior to the appearance of significant quantities of ultrafine aerosol particles. The strong coupling to boundary layer dynamics and growth of the mixed layer may provide a partial explanation for the apparent delay in the onset of nucleation at Bloomington and Indianapolis relative to MMSF (Table 2, see also the example from 22 May given in Fig. 6). It may be that the higher surface roughness and different energy balance of the forest means that mixed layer growth and entrainment from the residual layer is initiated earlier over the forest.

\subsection{Associations between organic and inorganic gas concentrations and ultra-fine aerosol particle composition and number concentration during nucleation events}

\subsubsection{Chemical controls on nucleation}

In keeping with prior research which has indicated that if the source strength for the nucleating vapors is strong enough to compete against the losses to the pre-existing particles (Kulmala et al., 2005; Pryor et al., 2010), gas-to-particle conversion can be observed in polluted air masses (e.g. in Atlanta, 
(a)

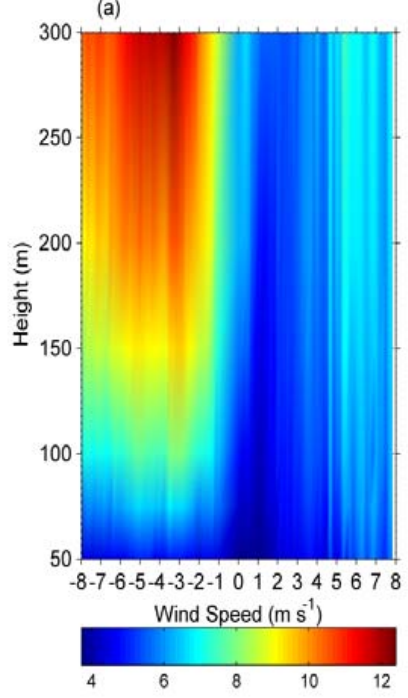

(c)

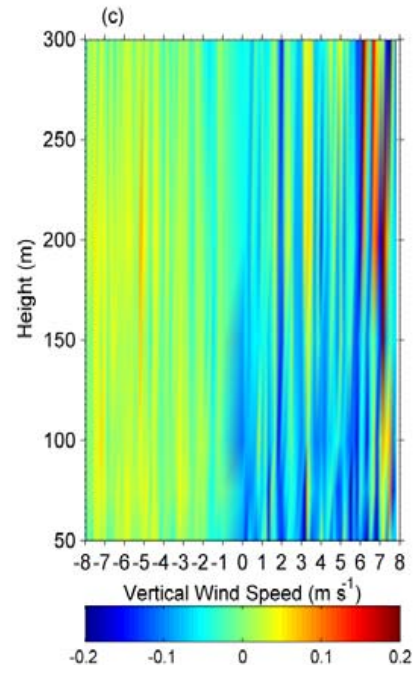

Fig. 10. Composites of data collected with the Natural Power ZephIR lidar deployed at MMSF during NIFTy event class A days. The data are 10-min average values and in each frame the time coordinate is given in terms of the time prior to the $10 \mathrm{~min}$ period when the maximum increase in $6-10 \mathrm{~nm}$ aerosol particle concentrations was observed at the 46-m measurement level. The individual frames show; the (a) profile of wind speeds, (b) profile of turbulence intensity (depicted as the $\log _{10}$ of the turbulence intensity) and (c) and vertical wind speeds.

GA (Stolzenburg et al., 2005), Pittsburgh, PA (Stanier et al., 2004a), Beijing, China (Wu et al., 2007) and even Mexico City (Iida et al., 2008)), analyses of data from NIFTy do not indicate a very strong influence of condensational sink (CS) on the occurrence or intensity of nucleation (as measured using the total number concentration of sub-30nm aerosol particles) (see Fig. S2). This is also consistent with relatively high aerosol particle loadings in the region and the high regional emissions of $\mathrm{SO}_{2}$ and $\mathrm{NH}_{3}$ that may mean nucleation can

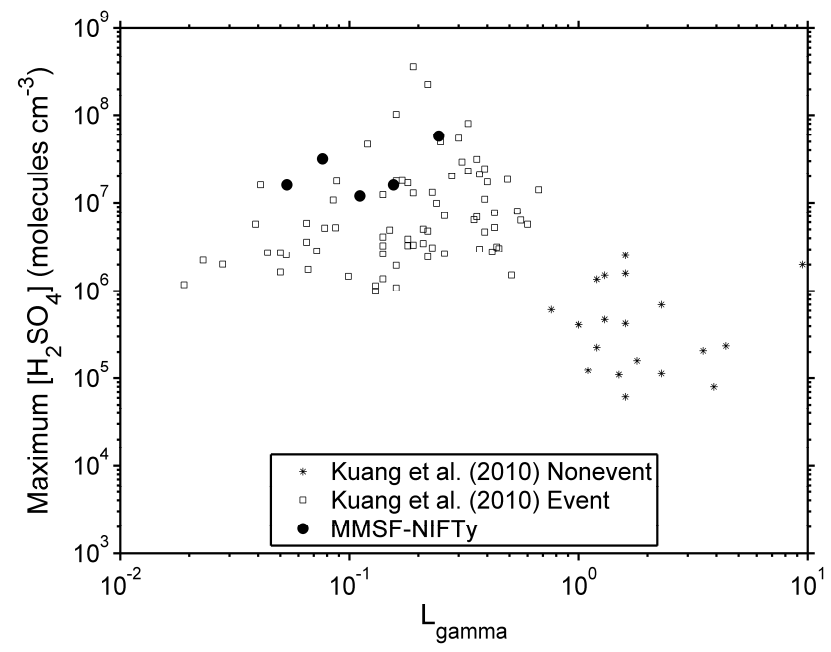

Fig. 11. Scatterplot of the maximum $\left[\mathrm{H}_{2} \mathrm{SO}_{4}\right]$ and the dimensionless nucleation parameter of Kuang et al. (2010) $\left(L_{\Gamma}\right)$ showing data for event and non-event days (i.e. days without aerosol particle nucleation) from Kuang et al. (2010), and derived from measurements on five event days at MMSF during NIFTy. Note the data from Kuang et al. (2010) are based on 5-min averaged, while those from MMSF are based on half-hour averages.

be initiated and sustained even when the condensational sink is comparatively strong. Average NP values at MMSF are demonstrably higher on event than non-event days (Fig. S2), although there is one event class B day that was characterized by relatively low NP values and one non-event day that exhibited high NP but no evidence for enhanced ultra-fine aerosol particle concentrations. Excluding those two outliers, $\mathrm{NP}$ values in excess of $3 \times 10^{-23} \mathrm{~W}$ m molecules ${ }^{-1} \mathrm{~K}^{-1}$ was observed on event days, while values below that threshold characterized non-event days.

Analysis of the dimensionless nucleation parameter $\left(L_{\Gamma}\right.$ from Eq. 3) of Kuang et al. (2010) on five A-class event days indicate that the threshold of 0.7 previously proposed based on data from five prior intensive field campaigns also appears robust for MMSF (Fig. 11). Indeed, all five events during NIFTy for which we have $\mathrm{H}_{2} \mathrm{SO}_{4}$ measurements are characterized by $L_{\Gamma}<0.3$. The intensity of particle production on these five days is inversely correlated with $L_{\Gamma}$ (correlation coefficient for $L_{\Gamma}$ vs. total aerosol particle number concentration $\sim-0.8$ ), though the small sample size precludes detailed interpretation.

A composite of $\mathrm{H}_{2} \mathrm{SO}_{4}$ concentrations at MMSF during event days (Fig. 12) indicate that concentrations typically increased by almost an order of magnitude upto three hours prior to the number concentration maximum, reached a maximum of $2 \times 10^{7}$ molecules $\mathrm{cm}^{-3}$ during the aerosol particle number concentration maximum and then subsequently declined. A qualitatively similar time profile is observed on non-event days, though the maximum $\mathrm{H}_{2} \mathrm{SO}_{4}$ concentrations 


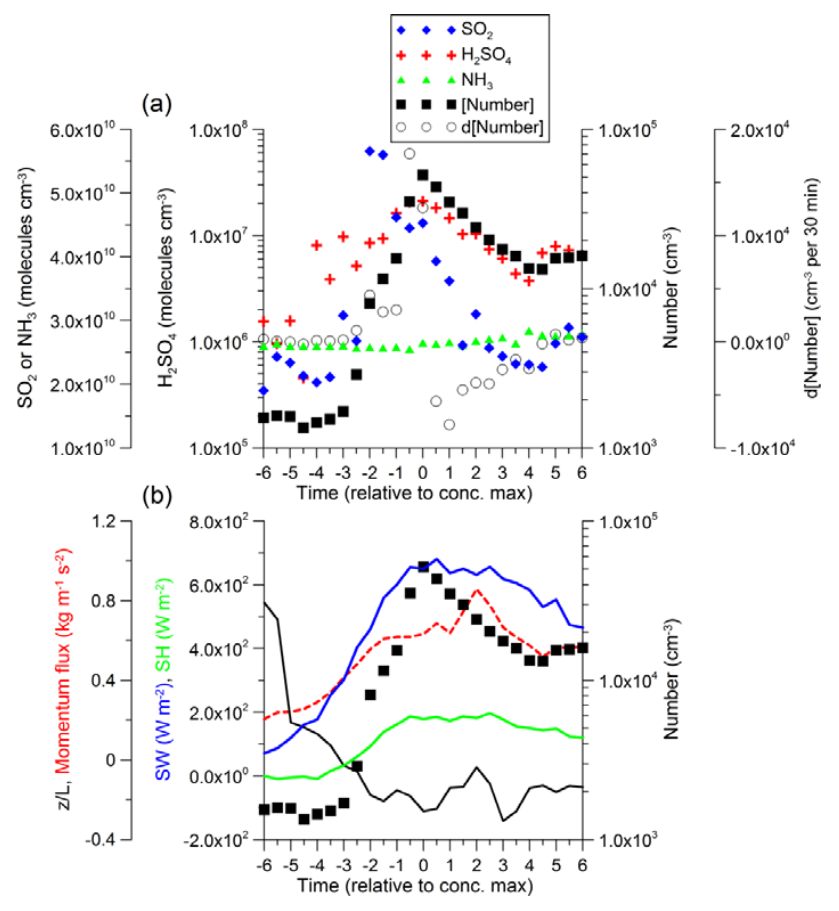

Fig. 12. (a) Average $\mathrm{NH}_{3}, \mathrm{SO}_{2}$ and $\mathrm{H}_{2} \mathrm{SO}_{4}$ concentrations at MMSF during NIFTy event class A, B and C days. The data are 30-min average values and the time co-ordinate is given in terms of the time prior to the $30 \mathrm{~min}$ period with maximum $6-30 \mathrm{~nm}$ aerosol particle number concentrations. Also shown is the average aerosol particle number concentration $(6-30 \mathrm{~nm})$ and the half-hour average change in ultrafine aerosol particle concentrations. (b) Average momentum flux, a stability index (measurement height divided by the Monin-Obukhov length, $z / L$ ), incoming shortwave radiation, and the sensible heat flux for the event days (time normalized as above for the gas concentrations).

on non-event days were almost an order of magnitude lower than on event days. The time-trace of average $\mathrm{NH}_{3}$ concentrations exhibited a quite different temporal profile. Average $\mathrm{NH}_{3}$ concentrations exhibited a small decline (of less than $5 \%$ ) during the period of increasing $\mathrm{H}_{2} \mathrm{SO}_{4}$ and ultra-fine aerosol particle number concentrations, and then increased (by approximately 10\%) during the remainder of the daylight hours. The increase in $\mathrm{H}_{2} \mathrm{SO}_{4}$ is likely due to entrainment of an elevated polluted layer during boundary layer growth and photochemical conversion of $\mathrm{SO}_{2}$ to $\mathrm{H}_{2} \mathrm{SO}_{4}$. Conversely $\mathrm{NH}_{3}$ is emitted principally from ground sources and the diurnal profile of $\mathrm{NH}_{3}$ is largely controlled by the diurnal profile of temperature and resultant $\mathrm{NH}_{3}$ emissions. The small reduction in $\mathrm{NH}_{3}$ concentrations during the period of nucleation (prior to the appearance of aerosol particles with diameters in excess of $6 \mathrm{~nm}$ ) may either be linked to dilution during boundary-layer growth or loss of $\mathrm{NH}_{3}$ to aerosol particles either in the process of ternary nucleation or condensational growth. Composites of the micro-meteorological parameters are consistent with interpretation of data from the lidar (see
Figs. 10 and 12). Prior to nucleation events at MMSF the data indicate a transition towards more unstable conditions (as manifest in the transition of the stability index $(z / L)$ from positive to negative values) and increased momentum fluxes, along with increased sensible heat flux. All are consistent with growth of the boundary layer in the early morning hours. The accompanying increase in solar radiation receipt would also lead to increased efficiency of $\mathrm{H}_{2} \mathrm{SO}_{4}$ production from $\mathrm{SO}_{2}$.

Measurements of $\mathrm{OH}$ were made sporadically from 23 May through 29 May 2008 to understand the behavior and role of $\mathrm{OH}$ prior to and during nucleation events. Composite diurnal profiles of $30 \mathrm{~s} \mathrm{OH}$ measurements for three nucleation days and two non-event days show a substantial difference in $\mathrm{OH}$ distribution throughout the day. On the three nucleation days, $\mathrm{OH}$ concentrations peaked around noon with an averaged peak concentration of $\sim 4 \times 10^{6}$ molecules $\mathrm{cm}^{-3}$. On non-event days $\mathrm{OH}$ concentrations were suppressed, reaching a maximum of approximately $8 \times 10^{5}$ molecules $\mathrm{cm}^{-3}$ by 09:00 LST with little fluctuation, before decreasing at approximately 17:00 LST. The absence of a noontime peak in $\mathrm{OH}$ concentrations on nonevents days is consistent with the observed much lower solar radiation flux (incoming shortwave radiation was $\leq 50 \%$ of the value on event days). Measured $\mathrm{OH}$ concentrations were suppressed further since measurements were performed at ground level, shaded by the forest canopy. While OH concentrations were nearly an order of magnitude greater on the three nucleation days, ground level $\mathrm{OH}$ was not likely to have contributed significantly to the increase in measured $\mathrm{H}_{2} \mathrm{SO}_{4}$ concentration in the lead up to the nucleation events. Sulfur dioxide measurements on event days 24 May and 25 May showed a morning peak between 08:00-09:00 (LST), at which time the average $\mathrm{OH}$ concentration was $<2 \times 10^{6}$ molecules $\mathrm{cm}^{-3}$. Complete conversion of $\mathrm{OH}$ to $\mathrm{H}_{2} \mathrm{SO}_{4}$ could not account for the measured $\mathrm{H}_{2} \mathrm{SO}_{4}$ at these times. The lack of sufficient $\mathrm{OH}$ at ground level to produce the $\mathrm{H}_{2} \mathrm{SO}_{4}$ concentrations measured in early morning and $\mathrm{H}_{2} \mathrm{SO}_{4}$ peaking around the time $\mathrm{SO}_{2}$ peaks on these days further supports the postulate of entrainment of both species from well above the forest canopy.

\subsubsection{Chemical controls on growth}

Using hourly GR derived for $6-30 \mathrm{~nm}$ diameter aerosol particles from the SMPS at MMSF and the approximation that the total condensing vapor concentration is $\sim 1.37 \times 10^{7} \mathrm{~cm}^{-3} \times \mathrm{GR}$ (Fiedler et al., 2005), gives a condensing vapor concentration of approximately $5.2 \times 10^{7}$ molecules $\mathrm{cm}^{-3}$ on 21 May 2008, and $5.0 \times 10^{7}$ molecules $\mathrm{cm}^{-3}$ on 22 May 2008 (see below for a discussion of the aerosol particle composition on these days). The average measured $\mathrm{H}_{2} \mathrm{SO}_{4}$ during these events were $1.23 \times 10^{7}$ molecules $\mathrm{cm}^{-3}$ and $1.24 \times 10^{7}$ molecules $\mathrm{cm}^{-3}$, respectively which implies the percentage contribution of 
$\mathrm{H}_{2} \mathrm{SO}_{4}$ to aerosol particle growth is approximately $24 \%$. The contribution of $\mathrm{H}_{2} \mathrm{SO}_{4}$ to growth on three other A-class event days ranged from 23 to $85 \%$, although these must be considered conservative estimates of the actual contribution of $\mathrm{H}_{2} \mathrm{SO}_{4}$ to initial aerosol particle growth since the $\mathrm{H}_{2} \mathrm{SO}_{4}$ measurements were taken below the forest canopy. Comparable estimates for approximately 20 events at Heidelberg and Hyytiälä were $4.3 \%$ and $5.9 \%$, respectively (Fiedler et al., 2005), while another study focused only on Hyytiälä gave an average of $8.9 \%$ and a range of 4.8 to $16.9 \%$ (Boy et al., 2005). Conversely, during some days $\mathrm{H}_{2} \mathrm{SO}_{4}$ contributed $100 \%$ to the growth in Atlanta (Stolzenburg et al., 2005). Thus southern Indiana appears to be a mid-point on the scale of relative importance of $\mathrm{H}_{2} \mathrm{SO}_{4}$, and the relatively high contribution of $\mathrm{H}_{2} \mathrm{SO}_{4}$ to aerosol particle growth at MMSF may reflect the abundance of both $\mathrm{H}_{2} \mathrm{SO}_{4}$ and $\mathrm{NH}_{3}$ in southern Indiana.

\subsubsection{Mass closure}

A mass closure for physical aerosol particle measurements and the size-resolved inorganic concentrations from the MOUDI and nano-MOUDI instruments was conducted to examine whether the ultra-fine aerosol particles exhibit evidence of the presence of a substantial fraction of organics. The mass concentration was derived from the SMPS and FMPS using an assumed aerosol particle density of $1.6 \mathrm{~g} \mathrm{~cm}^{-3}$. Of the inorganic ions measured, only $\mathrm{NH}_{4}^{+}$ and $\mathrm{SO}_{4}^{2-}$ were routinely present in the sub- $32 \mathrm{~nm}$ aerosol particles at MMSF. Comparisons of the sum of $\mathrm{NH}_{4}^{+}$and $\mathrm{SO}_{4}^{2-}$ concentrations from the nano-MOUDI and MOUDI with those from the physical size instruments indicates that within the uncertainty bounds, during nucleation event days the majority of the mass of sub-32 $\mathrm{nm}$ aerosol particles can be accounted for by $\mathrm{NH}_{4}^{+}$and $\mathrm{SO}_{4}^{2-}$ (plus associated water) (Fig. 13). While this mass closure is not definitive evidence that organics are not playing a role in nucleation and initial growth at MMSF, consistent with the preceding analysis of the contribution of $\mathrm{H}_{2} \mathrm{SO}_{4}$ to aerosol particle growth, it appears to indicate a dominant role for the inorganic gases. Beyond approximately $32 \mathrm{~nm}$ diameter, there is evidence for a greater role for organics. For example, for the size stages at 56 and $100 \mathrm{~nm}$, the mass of inorganics contributes only half of the total mass derived from the physical aerosol particle size distributions, which implies organics may dominate in this size range, and thus organic vapors may be significantly contributing to aerosol particle growth beyond approximately $30 \mathrm{~nm}$ diameter. The results are thus consistent with research from other forest environments that has resolved that neutralized sulfates are responsible for the initial formation and growth of aerosol particles, but they were not able to explain subsequent growth to observed sizes of over $50 \mathrm{~nm}$ (Boy et al., 2005; Ristovski et al., 2010), and with the study of aerosol particle growth in Leipzig Germany which found sulfuric acid explained the majority of growth

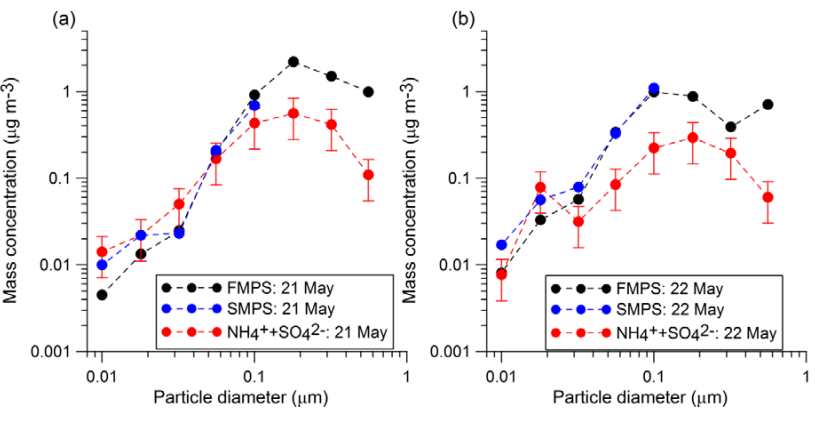

Fig. 13. Mass closure for physical aerosol particle measurement from the SMPS and FMPS versus inorganic concentrations from the nano-MOUDI and MOUDI operated at MMSF during the 21 and 22 May. The uncertainty bounds shown on the sum of the $\mathrm{NH}_{4}^{+}$ and $\mathrm{SO}_{4}^{2-}$ concentration are based on replica analysis of standards on the ion chromatograph.

(about $75 \%$ ) to approximately $20 \mathrm{~nm}$ but after that secondary organic compounds significantly contributed to the continued growth (Wehner et al., 2005).

\section{Concluding remarks}

Analyses of data from the spatial sampling and vertical profiles of aerosol particle concentrations in the lowest 200$300 \mathrm{~m}$ of the atmosphere during the NIFTy experiment indicate:

- High concentrations of ultrafine aerosol particles with a diameter below $20 \mathrm{~nm}$ and clear growth were observed on nearly half of sampling days, and were observed at all three sampling sites (in the small city of Bloomington, expansive forest of MMSF and downwind of the urban core of Indianapolis). The observed increase of ultrafine aerosol particles at the MMSF tower site during nucleation events (of approximately $2 \times 10^{4} \mathrm{~cm}^{-3}$ for $D p \geq 10 \mathrm{~nm}$ ) is representative of increases observed through a layer of at least $300 \mathrm{~m}$ in depth. The intensity of the nucleation events is in good agreement with recent model results from PMCAMx-UF for the Midwestern USA (Jung et al., 2010).

- There is a relatively high degree of coherence in the occurrence and intensity of new aerosol particle formation over spatial scales of at least $80 \mathrm{~km}$. The very similar GR from these sites implies the nucleation events are both regional in occurrence and regionally homogeneous in terms of the subsequent aerosol particle growth, since the specific local use appears to play little role in causing site-to-site variations in GR. For example, on 22 May the GR at MMSF computed from the SMPS was approximately $4 \mathrm{~nm} \mathrm{hr}^{-1}$ averaged over the $6 \mathrm{~h}$ prior to the nGMD minimum, while the comparable 
value for Bloomington was approximately $5 \mathrm{~nm} \mathrm{hr}^{-1}$. The condensational sinks (CS) computed for $1 \mathrm{~h}$ prior to the event initiation at the two sites (as computed based on data from the SMPS at Bloomington and the SMPS and FMPS at MMSF) were also very similar; $1.36 \times 10^{-2} \mathrm{~s}^{-1}$ and $1.45 \times 10^{-2} \mathrm{~s}^{-1}$, respectively.

- On the basis of box modeling, approximately half of the aerosol particle number concentration reduction in the hour after termination of nucleation is due to coagulation, about one-quarter is due to dry deposition to the forest and one quarter is due to dilution resulting from mixed layer growth and entrainment of relatively ultrafine aerosol particle free troposphere air.

Analysis of data from in situ meteorological measurements indicates:

- Nucleation is strongly influenced by cloud cover particularly during the early morning hours. A-events were only observed on days when the fractional cloud cover was less than $30 \%$.

- Nucleation was most frequently observed in the late morning (09:00 to 12:00 LST), and is coupled to a clear transition from a strongly stratified atmosphere with low turbulence intensity and weak vertical velocities, to much a weaker vertical gradient of wind speed, increased turbulence intensity and stronger downwards vertical velocities, consistent with growth of the mixed layer and entrainment of air from the residual layer. This transition occurs on average one hour prior to the appearance of significant quantities of ultrafine aerosol particles. The strong coupling to boundary layer dynamics and growth of the mixed layer may provide a partial explanation for the apparent delay in the onset of nucleation at Bloomington and Indianapolis relative to MMSF. It may be that the higher surface roughness and different energy balance of the forest means that mixed layer growth and entrainment from the residual layer is initiated earlier over the forest.

Analysis of the aerosol particle size distributions and gasphase concentrations indicates:

- Nucleation intensity is not very strongly determined by the prevailing condensational sink (CS), but there is a strong correlation between a modified version of the Nucleation Parameter (NP) from Boy and Kulmala (2002) (see Supplement). Analysis of the dimensionless nucleation parameter $\left(L_{\Gamma}\right)$ of Kuang et al. (2010) on five A-class event days indicates the threshold of 0.7 for nucleation occurrence (i.e. nucleation is only predicted for $L_{\Gamma}<0.7$ ) as previously proposed, appears robust for MMSF.
- Nucleation is always preceded by an increase in $\mathrm{H}_{2} \mathrm{SO}_{4}$ concentrations but appears to be independent of $\mathrm{NH}_{3}$ concentrations, possibly due to the high observed $\mathrm{NH}_{3}$ concentrations. Mean morning $\mathrm{H}_{2} \mathrm{SO}_{4}$ concentrations have a relatively strong positive relationship with ultrafine aerosol particle number concentrations $\left(r^{2}=0.5\right.$ for a power law fit, Fig. S3). A conservative estimation of the percentage contribution of $\mathrm{H}_{2} \mathrm{SO}_{4}$ to aerosol particle growth (for sub- $30 \mathrm{~nm}$ aerosol particles) on five event class A days ranged from 23 to $85 \%$.

- A mass closure for physical aerosol particle measurements and the size-resolved inorganic concentrations indicates the overwhelming majority of the mass of sub$32 \mathrm{~nm}$ aerosol particles can be accounted for by $\mathrm{NH}_{4}^{+}$ and $\mathrm{SO}_{4}^{2-}$ (plus associated water). The mass closure indicates organics may be playing a larger role in growth beyond $30 \mathrm{~nm}$ diameter.

\section{Supplement related to this article is available online at: http://www.atmos-chem-phys.net/11/1641/2011/ acp-11-1641-2011-supplement.pdf.}

Acknowledgements. This research was funded by a grant from NSF (0544745 and supplement). SCP also acknowledges a fellowship from Aarhus University, Denmark. The ceilometers and micro-meteorological data used herein were collected under funding from the Office of Science (BER), US Department of Energy, grant DE-FG02-07ER64371 (D. Dragoni et al., principal investigators). Technical support from Steve Scott, and the field assistance of M. Brothers, J. Butler, W. Hull, L. Mauldin III, H. Porter, E. Riley A. Spaulding, D. Valyou, D. Young and E. Zito is gratefully acknowledged. We also gratefully acknowledge the efforts of T. Jobson, and the assistance of both the members of the Monroe County Radio Control Club and the Indiana Department of Environmental Management. Thanks also for helpful comments from two anonymous reviewers.

Edited by: N. M. Donahue

\section{References}

Alley, R., Berntsen, T., Bindoff, N., Chen, Z., Chidthaisong, A., Friedlingstein, P., Gregory, J., Hegerl, G., Heimann, M., Hewitson, B., Hoskins, B., Joos, F., Jouzel, J., Kattsov, V., Lohmann, U., Manning, M., Matsuno, T., Molina, M., Nicholls, N., Overpeck, J., Qin, D., Raga, G., Ramaswamy, V., Ren, J., Rusticucci, M., Solomon, S., Somerville, R., Stocker, T., Stott, P., Stouffer, R., Whetton, P., Wood, R., and Wratt, D.: Summary for policymakers, in: Climate Change 2007: The Physical Science Basis. Contribution of Working Group I to the Fourth Assessment Report of the Intergovernmental Panel on Climate Change, edited by: Solomon, S., Qin, D., Manning, M., Chen, Z., Marquis, M., Averyt, K. B., Tignor, M., and Miller, H. L., Cambridge University Press, Cambridge, UK, 2007. 
Asbach, C., Kaminski, H., Fissan, H., Monz, C., Dahmann, D., Mulhopt, S., Paur, H. R., Kiesling, H. J., Herrmann, F., Voetz, M., and Kuhlbusch, T. A. J.: Comparison of four mobility particle sizers with different time resolution for stationary exposure measurements, J. Nanopart. Res., 11, 1593-1609, doi:10.1007/s11051-009-9679-x, 2009.

Batchvarova, E. and Gryning, S.-E.: An applied model for the height of the daytime mixed layer and the entrainment zone, Bound.-Lay. Meteorol., 71, 311-323, 1994.

Berresheim, H., Elste, T., Plass-Dülmer, C., Eisele, F. L., and Tanner, D. J.: Chemical ionization mass spectrometer for longterm measurements of atmospheric $\mathrm{OH}$ and $\mathrm{H} 2 \mathrm{SO} 4$, International Journal of Mass Spectrometry, 202, 91-109, 2000.

Boy, M. and Kulmala, M.: Nucleation events in the continental boundary layer: Influence of physical and meteorological parameters, Atmos. Chem. Phys., 2, 1-16, doi:10.5194/acp-2-1-2002, 2002.

Boy, M., Kulmala, M., Ruuskanen, T. M., Pihlatie, M., Reissell, A., Aalto, P. P., Keronen, P., Dal Maso, M., Hellen, H., Hakola, H., Jansson, R., Hanke, M., and Arnold, F.: Sulphuric acid closure and contribution to nucleation mode particle growth, Atmos. Chem. Phys., 5, 863-878, doi:10.5194/acp-5-863-2005, 2005.

Coe, H., Williams, P. I., McFiggans, G., Gallagher, M. W., Beswick, K. M., Bower, K. N., and Choularton, T. W.: Behavior of ultrafine particles in continental and marine air masses at a rural site in the United Kingdom, J. Geophys. Res., 105, 26891-26905, 2000

Dal Maso, M., Kulmala, M., Riipinen, I., Wagner, R., Hussein, T., Aalto, P. P., and Lehtinen, K. E. J.: Formation and growth of fresh atmospheric aerosols: eight years of aerosol size distribution data from SMEAR II, Hyytiala, Finland, Boreal Environ. Res., 10, 323-336, 2005

Dal Maso, M., Sogacheva, L., Aalto, P. P., Riipinen, I., Komppula, M., Tunved, P., Korhonen, L., Suur-Uski, V., Hirsikko, A., Kurten, T., Kerminen, V. M., Lihavainen, H., Viisanen, Y., Hansson, H. C., and Kulmala, M.: Aerosol size distribution measurements at four Nordic field stations: identification, analysis and trajectory analysis of new particle formation bursts, Tellus B-Chem. Phys. Meteorol., 59, 350-361, 10.1111/j.16000889.2007.00267.x, 2007.

Eisele, F. and Tanner, D. J.: Measurement of the gas phase concentration of $\mathrm{H} 2 \mathrm{SO} 4$ and methane sulfonic acid and estimates of $\mathrm{H} 2 \mathrm{SO} 4$ production and loss in the atmosphere, J. Geophys. Res., 98, 9011-9010, 1993.

Emeis, S., Schafer, K., and Munkel, C.: Surface-based remote sensing of the mixing-layer height - a review, Meteorologische Zeitschrift, 17, 621-630, doi:10.1127/0941-2948/2008/0312, 2008.

Fairall, C. W. and Larsen, S. E.: Dry deposition, surface production and dynamics of aerosols in the marine boundary layer, Atmos. Environ., 18, 69-77, 1984.

Fiedler, V., Dal Maso, M., Boy, M., Aufmhoff, H., Hoffmann, J., Schuck, T., Birmili, W., Hanke, M., Uecker, J., Arnold, F., and Kulmala, M.: The contribution of sulphuric acid to atmospheric particle formation and growth: a comparison between boundary layers in Northern and Central Europe, Atmos. Chem. Phys., 5, 1773-1785, doi:10.5194/acp-5-1773-2005, 2005.

Frank, B. P., Saltiel, S., Hogrefe, O., Grygas, J., and Lala, G. G.: Determination of mean particle size using the electrical aerosol detector and the condensation particle counter: Comparison with the scanning mobility particle sizer, J. Aerosol Sci., 39, 19-29, doi:10.1016/j.jaerosci.2007.09.008, 2008.

Gagné, S., Nieminen, T., Kurtn, T., Manninen, H. E., Petäjä, T., Laakso, L., Kerminen, V.-M., Boy, M., and Kulmala, M.: Factors influencing the contribution of ion-induced nucleation in a boreal forest, Finland, Atmos. Chem. Phys., 10, 3743-3757, doi:10.5194/acp-10-3743-2010, 2010.

Grosjean, D.: In situ organic aerosol formation during a smog episode: estimated production and chemical functionality, Atmos. Environ., 26A, 953-963, 1992.

Hussein, T., Junninen, H., Tunved, P., Kristensson, A., Dal Maso, M., Riipinen, I., Aalto, P. P., Hansson, H.-C., Swietlicki, E., and Kulmala, M.: Time span and spatial scale of regional new particle formation events over Finland and Southern Sweden, Atmos. Chem. Phys., 9, 4699-4716, doi:10.5194/acp-9-4699-2009, 2009.

Iida, K., Stolzenburg, M. R., McMurry, P. H., and Smith, J. N.: Estimating nanoparticle growth rates from sizedependent charged fractions: Analysis of new particle formation events in Mexico City, J. Geophys. Res., 113, D05207, doi:10.1029/2007jd009260, 2008.

Jacobson, M. Z., Turco, R. P., Jensen, E., and Toon, O. B.: Modeling coagulation among particles of different composition and size, Atmos. Environ., 28, 1327-1338, 1994.

Jeong, C. H. and Evans, G. J.: Inter-Comparison of a Fast Mobility Particle Sizer and a Scanning Mobility Particle Sizer Incorporating an Ultrafine Water-Based Condensation Particle Counter, Aerosol Science and Technology, 43, 364-373, 10.1080/02786820802662939, 2009.

Jeong, C. H., Evans, G. J., McGuire, M. L., Chang, R. Y. W., Abbatt, J. P. D., Zeromskiene, K., Mozurkewich, M., Li, S. M., and Leaitch, W. R.: Particle formation and growth at five rural and urban sites, Atmos. Chem. Phys., 10, 7979-7995, doi:10.5194/acp10-7979-2010, 2010.

Jung, J. G., Fountoukis, C., Adams, P. J., and Pandis, S. N.: Simulation of in situ ultrafine particle formation in the eastern United States using PMCAMx-UF, J. Geophys. Res., 115, D03203, doi:10.1029/2009jd012313, 2010.

Kaimal, J. C. and Finnigan, J. J.: Atmospheric Boundary Layer Flows: Their Structure and Measurement, Oxford University Press, New York, USA, 289 pp., 1994.

Komppula, M., Sihto, S.-L., Korhonen, H., Lihavainen, H., Kerminen, V.-M., Kulmala, M., and Viisanen, Y.: New particle formation in air mass transported between two measurement sites in Northern Finland, Atmos. Chem. Phys., 6, 2811-2824, doi:10.5194/acp-6-2811-2006, 2006.

Korhonen, P., Kulmala, M., Laaksonen, A., Viisanen, Y., McGraw, R., and Seinfeld, J. H.: Ternary nucleation of $\mathrm{H}_{2} \mathrm{SO}_{4}, \mathrm{NH}_{3}$, and $\mathrm{H}_{2} \mathrm{O}$ in the atmosphere, J. Geophys. Res., 104, 26349-26353, 1999.

Kuang, C., Riipinen, I., Sihto, S.-L., Kulmala, M., McCormick, A V., and McMurry, P. H.: An improved criterion for new particle formation in diverse atmospheric environments, Atmos. Chem. Phys., 10, 8469-8480, doi:10.5194/acp-10-8469-2010, 2010.

Kulmala, M. and Kerminen, V. M.: On the formation and growth of atmospheric nanoparticles, Atmos. Res., 90, 132-150, doi:10.1016/j.atmosres.2008.01.005, 2008.

Kulmala, M., Dal Maso, M., Mäkelä, J., Pirjola, L., Vakeva, M., 
Aalto, P., Miikkulainen, P., Hameri, K., and O'Dowd, C. D.: On the formation, growth and composition of nucleation mode particles, Tellus, 53B, 479-490, 2001.

Kulmala, M., Vehkamaki, H., Petaja, T., Dal Maso, M., Lauri, A., Kerminen, V.-M., Birmili, W., and McMurry, P.: Formation and growth rates of ultrafine atmospheric particles: a review of observations, J. Aerosol Sci., 35, 143-176, 2004.

Kulmala, M., Petj, T., Mnkknen, P., Koponen, I. K., Dal Maso, M., Aalto, P. P., Lehtinen, K. E. J., and Kerminen, V.-M.: On the growth of nucleation mode particles: source rates of condensable vapor in polluted and clean environments, Atmos. Chem. Phys., 5, 409-416, doi:10.5194/acp-5-409-2005, 2005.

Lauros, J., Nilsson, E. D., Vehkamaki, H., and Kulmala, M.: Atmospheric variability and binary homogeneous nucleation: A parametrisation and conditions required for a significant effect, Atmos. Res., 82, 503-513, 2006.

Lauros, J., Nilsson, E. D., Dal Maso, M., and Kulmala, M.: Contribution of mixing in the ABL to new particle formation based on observations, Atmos. Chem. Phys., 7, 4781-4792, doi:10.5194/acp-7-4781-2007, 2007.

Lenschow, D. H., Krummel, P. B., and Siems, S. T.: Measuring entrainment, divergence, and vorticity on the mesoscale from aircraft, Journal of Atmos. Ocean. Technol., 16, 1384-1400, 1999.

Manninen, H. E., Nieminen, T., Asmi, E., Gagné, S., Häkkinen, S., Lehtipalo, K., Aalto, P., Vana, M., Mirme, A., Mirme, S., Hõrrak, U., Plass-Dülmer, C., Stange, G., Kiss, G., Hoffer, A., Tõrö, N., Moerman, M., Henzing, B., de Leeuw, G., Brinkenberg, M., Kouvarakis, G. N., Bougiatioti, A., Mihalopoulos, N., O'Dowd, C., Ceburnis, D., Arneth, A., Svenningsson, B., Swietlicki, E., Tarozzi, L., Decesari, S., Facchini, M. C., Birmili, W., Sonntag, A., Wiedensohler, A., Boulon, J., Sellegri, K., Laj, P., Gysel, M., Bukowiecki, N., Weingartner, E., Wehrle, G., Laaksonen, A., Hamed, A., Joutsensaari, J., Petj, T., Kerminen, V.-M., and Kulmala, M.: EUCAARI ion spectrometer measurements at 12 European sites - analysis of new particle formation events, Atmos. Chem. Phys., 10, 7907-7927, doi:10.5194/acp-10-79072010, 2010.

Mauldin III, R., Cantrell, C., Zindlo, M., Ridley, B., Weber, R., and Eisele, F.: Measurements of $\mathrm{OH}, \mathrm{H} 2 \mathrm{SO} 4$, and MSA during Tropospheric Ozone Production about the Spring Equinox (TOPSE), J. Geophys. Res., 108, 8366, doi:8310.1029/2002JD002295, 2003.

McMurry, P. H., Fink, M., Sakurai, H., Stolzenburg, M. R., Mauldin, R. L., Smith, J., Eisele, F., Moore, K., Sjostedt, S., Tanner, D., Huey, L. G., Nowak, J. B., Edgerton, E., and Voisin, D.: A criterion for new particle formation in the sulfur-rich Atlanta atmosphere, J. Geophys. Res., 110, D22S03, doi:10.1029/2005JD005901, 2005.

Metzger, A., Verheggen, B., Dommen, J., Duplissy, J., Prevot, A. S. H., Weingartner, E., Riipinen, I., Kulmala, M., Spracklen, D. V., Carslaw, K. S., and Baltensperger, U.: Evidence for the role of organics in aerosol particle formation under atmospheric conditions, Proc. Natl. Acad. Sci. USA, 107, 6646-6651, doi:10.1073/pnas.0911330107, 2010.

Napari, I., Noppel, M., Vehkamaki, H., and Kulmala, M.: Parameterization of ternary nucleation rates for $\mathrm{H}_{2} \mathrm{SO}_{4}-\mathrm{NH}_{3}-\mathrm{H}_{2} \mathrm{O}$ vapors, J. Geophys. Res., 107, 4381, doi10.1029/2002JD002132, 2002.

Nieminen, T., Manninen, H. E., Sihto, S. L., Yli-Juuti, T., Mauldin,
R. L., Petaja, T., Riipinen, I., Kerminen, V. M., and Kulmala, M.: Connection of Sulfuric Acid to Atmospheric Nucleation in Boreal Forest, Environ. Sci. Technol., 43, 4715-4721, doi:10.1021/es803152j, 2009.

Nilsson, E. D. and Kulmala, M.: The potential for atmospheric mixing processes to enhance the binary nucleation rate, J. Geophys. Res., 103, 1381-1389, 1998.

Nilsson, E. D., Rannik, Ü., Kulmala, M., Buzorius, G., and O'Dowd, C.: Effects of continental boundary layer evolution, convection, turbulence and entrainment, on aerosol formation, Tellus, 53B, 441-461, 2001.

O’Dowd, C. D., Yoon, Y. J., Junkermann, W., Aalto, P., Kulmala, M., Lihavainen, H., and Viisanen, Y.: Airborne measurements of nucleation mode particles II: boreal forest nucleation events, Atmos. Chem. Phys., 9, 937-944, doi:10.5194/acp-9-937-2009, 2009.

Paasonen, P., Nieminen, T., Asmi, E., Manninen, H. E., Petäjä, T., Plass-Dülmer, C., Flentje, H., Birmili, W., Wiedensohler, A., Hõrrak, U., Metzger, A., Hamed, A., Laaksonen, A., Facchini, M. C., Kerminen, V.-M., and Kulmala, M.: On the roles of sulphuric acid and low-volatility organic vapours in the initial steps of atmospheric new particle formation, Atmos. Chem. Phys., 10, 11223-11242, doi:10.5194/acp-10-11223-2010, 2010.

Petäjä, T., Kerminen, V.-M., Dal Maso, M., Junninen, H., Koponen, I. K., Hussein, T., Aalto, P. P., Andronopoulos, S., Robin, D., Hämeri, K., Bartzis, J. G., and Kulmala, M.: Submicron atmospheric aerosols in the surroundings of Marseille and Athens: physical characterization and new particle formation, Atmos. Chem. Phys., 7, 2705-2720, doi:10.5194/acp-72705-2007, 2007.

Place, P. F., Ziemba, L. D., and Griffin, R. J.: Observations of nucleation-mode particle events and size distributions at a rural New England site, Atmos. Environ., 44, 88-94, doi:10.1016/j.atmosenv.2009.09.030, 2010.

Pryor, S. C., Barthelmie, R. J., Sørensen, L., and Jensen, B.: Ammonia concentrations and fluxes over a forest in the midwestern USA, Atmos. Environ., 35, 5645-5656, 2001.

Pryor, S. C. and Spaulding, A. M.: Air quality in Indiana, in: Indiana's Weather and Climate, edited by: Oliver, J. E., Indiana University Press, Bloomington, Indiana, 57-62, 2009.

Pryor, S. C., Barthelmie, R. J., Spaulding, A. M., Larsen, S. E., and Petroff, A.: Size-resolved aerosol particle fluxes over forests, J. Geophys. Res., 114, D18212, doi:10.1029/2009JD012248, 2009.

Pryor, S. C., Spaulding, A. M., and Barthelmie, R.: New particle formation in the Midwestern USA: Event characteristics, meteorological context and vertical profiles, Atmos. Environ., 44, 4413-4425, 2010.

Ristovski, Z. D., Suni, T., Kulmala, M., Boy, M., Meyer, N. K., Duplissy, J., Turnipseed, A., Morawska, L., and Baltensperger, U.: The role of sulphates and organic vapours in growth of newly formed particles in a eucalypt forest, Atmos. Chem. Phys., 10, 2919-2926, doi:10.5194/acp-10-2919-2010, 2010.

Sakurai, H., Fink, M., McMurry, P. H., Mauldin, L., Moore, K. F., Smith, J. N., and Eisele, F. L.: Hygroscopicity and volatility of 4-10 nm particles during summertime atmospheric nucleation events in urban Atlanta, J. Geophys. Res., 110, D22S04, doi:10.1029/2005JD005918, 2005.

Schwartz, S. E., Charlson, R. J., Kahn, R. A., Ogren, J. A., and Rodhe, H.: Why hasn't Earth warmed as much as expected?, J. 
Climate, 23, 2453-2464, 10.1175/2009jcli3461.1, 2010.

Siebert, H., Stratmann, F., and Wehner, B.: First observations of increased ultrafine particle number concentrations near the inversion of a continental planetary boundary layer and its relation to ground-based measurements, Geophys. Res. Lett., 31, L09102, doi:10.1029/2003GL019086, 2004.

Sipila, M., Berndt, T., Petäjä, T., Brus, D., Vanhanen, J., Stratmann, F., Patokoski, J., Mauldin, R. L., Hyvarinen, A. P., Lihavainen, H., and Kulmala, M.: The role of sulfuric acid in atmospheric nucleation, Science, 327, 1243-1246, doi:10.1126/science.1180315, 2010.

Spracklen, D. V., Carslaw, K. S., Kulmala, M., Kerminen, V.-M., Mann, G. W., and Sihto, S.-L.: The contribution of boundary layer nucleation events to total particle concentrations on regional and global scales, Atmos. Chem. Phys., 6, 5631-5648, doi:10.5194/acp-6-5631-2006, 2006.

Stanier, C., Khlystov, A., and Pandis, S.: Nucleation events during the Pittsburgh Air Quality Study: Description and relation to key meteorological, gas phase and aerosol parameters, Aerosol Sci. Technol., 38, 253-264, 2004a.

Stanier, C., Khlystov, A., and Pandis, S.: Ambient aerosol size distributions and number concentrations measured durign the Pittsburgh Air Quality Study (PAQS), Atmos. Environ., 38, 32753284, 2004b.

Stolzenburg, M. R., McMurry, P. H., Sakurai, H., Smith, J. N., Mauldin III, R. L., Eisele, F. L., and Clement, C. F.: Growth rates of freshly nucleated atmospheric particles in Atlanta, J. Geophys. Res., 110, D22S05, doi:10.1029/2005JD005935, 2005.

Stull, R. B.: An introduction to boundary layer meteorology, ISBN 90-277-2768-6 ed., Kluwer Publications Ltd, Dordrecht, The Netherlands, 666 pp., 1988.

Tammet, H., Mirme, A., and Tamm, E.: Electrical Aerosol Spectrometer of Tartu University, Atmospheric Research, 62, 315324, 2002.

Wagner, R., Mikkelsen, T., and Courtney, M.: Investigation of turbulence measurements with a continuous wave, conically scanning LiDAR, Risoe DTU., Roskilde, 23 pp., 2009.

Weber, R. J., Marti, J. J., McMurry, P. H., Eisele, F. L., Tanner, D. J., and Jefferson, A.: Measurements of new particle formation and ultrafine particle growth rates at a clean continental site, J. Geophys. Res., 102, 4375—4385, 1997.

Weber, R. J., Chen, G., Davis, D., Mauldin, R. L., Tanner, D., Eisele, F., Clarke, A. D., Thornton, D., and Bandy, A.: Measurements of enhanced $\mathrm{H} 2 \mathrm{SO} 4$ and $3-4 \mathrm{~nm}$ particles near a frontal cloud during the First Aerosol Characterization Experiment (ACE 1), J. Geophys. Res., 106, 24107-24117, 2001.
Wehner, B., Petäjä, T., Boy, M., Engler, C., Birmili, W., Tuch, T., Wiedensohler, A., and Kulmala, M.: The contribution of sulfuric acid and non-volatile compounds on the growth of freshly formed atmospheric aerosols, Geophys. Res. Lett., 32, doi:10.1029/2005GL023827, 2005.

Wehner, B., Siebert, H., Stratmann, F., Tuch, T., Wiedensohler, A., Petäjä, T., Dal Maso, M., and Kulmala, M.: Horizontal homogeneity and vertical extent of new particle formation events, Tellus B-Chem. Phys. Meteorol., 59, 362-371, doi:10.1111/j.16000889.2007.00260.x, 2007.

Wehner, B., Siebert, H., Ansmann, A., Ditas, F., Seifert, P., Stratmann, F., Wiedensohler, A., Apituley, A., Shaw, R. A., Manninen, H. E., and Kulmala, M.: Observations of turbulence-induced new particle formation in the residual layer, Atmos. Chem. Phys., 10, 4319-4330, doi:10.5194/acp-10-4319-2010, 2010.

Wu, Z. J., Hu, M., Liu, S., Wehner, B., Bauer, S., Maßling, A. M., Wiedensohler, A., Petäjä, T., Dal Maso, M., and Kulmala, M.: New particle formation in Beijing, China: Statistical analysis of a 1-year data set, J. Geophys. Res., 112, 10.1029/2006jd007406, 10.1029/2006jd007406, 2007.

Young, L. H., Benson, D. R., Montanaro, W. M., Lee, S. H., Pan, L. L., Rogers, D. C., Jensen, J., Stith, J. L., Davis, C. A., Campos, T. L., Bowman, K. P., Cooper, W. A., and Lait, L. R.: Enhanced new particle formation observed in the northern midlatitude tropopause region, J. Geophys. Res., 112, D10218, doi:10.1029/2006jd008109, 2007.

Yu, F. and Luo, G.: Simulation of particle size distribution with a global aerosol model: contribution of nucleation to aerosol and CCN number concentrations, Atmos. Chem. Phys., 9, 76917710, doi:10.5194/acp-9-7691-2009, 2009.

Yue, D. L., Hu, M., Wu, Z. J., Wang, Z. B., Guo, S., Wehner, B., Nowak, A., Achtert, P., Wiedensohler, A., Jung, J., Kim, Y. J., and Liu, S.: Characteristics of aerosol size distributions and new particle formation in the summer in Beijing, J. Geophys. Res., 114, D00G12, doi:10.1029/2008jd010894, 2009.

Zhang, Q., Stanier, C., Canagaratna, M., Jayne, J., Worsnop, D. R., Pandis, S., and Jimenez, J.: Insights into the chemistry of new particle formation and growth events in Pittsburgh based on Aerosol Mass Spectrometry, Environ. Sci. Technol., 38, 47974809, 2004a.

Zhang, R. Y., Suh, I., Zhao, J., Zhang, D., Fortner, E. C., Tie, X. X., Molina, L. T., and Molina, M. J.: Atmospheric new particle formation enhanced by organic acids, Science, 304, 1487-1490, 2004b. 